\title{
Wood exploitation in a major pre-colonial West African iron production centre (Bassar, Togo)
}

\author{
Barbara Eichhorn ${ }^{\mathrm{a}, ~}$, Caroline Robion-Brunner ${ }^{\mathrm{b}}$ \\ ${ }^{a}$ Goethe-University, Institute of Archaeological Sciences, Department of Pre- and Protohistory, Norbert-Wollheim-Platz 1, D-60629, Frankfurt, Germany \\ ${ }^{\mathrm{b}}$ Université de Toulouse 2 le Mirail, UMR 5608,TRACES, Maison de la recherche - Bât. 26, 5 allée Antonio MACHADO, F-31058, Toulouse Cedex 9, France
}

\section{A R T I C L E I N F O}

\section{Article history:}

Received 15 June 2016

Received in revised form

24 August 2017

Accepted 31 August 2017

Available online 12 September 2017

\section{Keywords:}

Iron smelting

West Africa

Wood use

Charcoal

Sustainability

Agroforestry parklands

\begin{abstract}
A B S T R A C T
Local iron production played a major role in the pre-colonial West African economy and certain metallurgical centres operated on an industrial magnitude. One of them is the Bassar area in central Togo where the onset of iron metallurgy is considered to date back to the $3^{\text {rd }}-4$ th century $B C$, even though only from the 14th century AD onwards the area experienced distinct production intensification. High-level iron production lasted as late as the early 20th century.

Bassar iron metallurgy was often considered to have caused massive deforestation and vegetation degradation, mainly due to wood exploitation for charcoal production, specifically to fuel iron smelting furnaces. The study presented here is the first to test this assumption using anthracological methods, supplemented by ethnohistorical interviews and archaeometallurgical investigations.

The focus of our investigations is on two sites, Tchogma and Tatré. The charcoal assemblages at both sites and during all production periods are dominated by trees and shrubs with dense wood. According to our ethnohistorical interviews, hard wood species were considered particularly suitable for iron smelting, including several species with a strong capacity to re-sprout after coppicing.

The taxon composition of the charcoal assemblages from metallurgical waste heaps generally corresponds to the oral traditions. In addition to the taxa mentioned by the interviewees, useful fruit trees such as the shea butter tree (Vitellaria paradoxa) were regularly used as fuel for ironworking. This demonstrates the exploitation of agroforestry parklands, which is providing evidence that arable land was already occupying a vast land surface of the Bassar area.

The results of our study seem inconsistent with the previous idea of massive vegetation degradation due to the impact of wood exploitation for iron metallurgy in Bassar. Three main factors contradict previous general deforestation assumptions: 1 . The anthracological results indicate the use of taxa with the ability to re-sprout, which probably allowed for fast woodland regeneration; 2 . We consider the area to possess a higher biomass reproduction capacity in comparison to areas further north investigated in our previous studies; 3 . The development of local craft specialisation scattered the impact of wood use on the Bassar landscape, thereby, preventing complete local deforestation.

Our re-evaluation of Bassar slag amounts indicates fuel consumption was higher than previously thought. The over-exploitation of certain preferred taxa, particularly species with a restricted capacity to re-sprout, and local vegetation changes around the smelting sites is likely, although such modifications are not unequivocally reflected in the charcoal data.
\end{abstract}

() 2017 Elsevier Ltd and INQUA. All rights reserved.

\section{Introduction}

The beginnings of iron metallurgy in West Africa are often

\footnotetext{
* Corresponding author.

E-mail addresses: b.eichhorn@em.uni-frankfurt.de (B. Eichhorn), crobion@univtlse2.fr (C. Robion-Brunner).
}

difficult to detect archaeologically and very early claims have been substantially debated (e.g. Killick, 2004; Alpern, 2005).

The transition from initial, sporadic iron metallurgy and use to the 'generalization' of iron, i.e., the establishment, regional spread and general availability of iron objects, virtually took place during the first millennium BC in some parts of West Africa; whereas, in other regions, the first iron implements only appeared at the turn of the first to the second millennium AD (Huysecom, 2001; Chirikure, 
2015). During the phase of early sporadic use, this new metal was considered prestigious and of no special importance for daily life. It seems unlikely that this early low-level iron metallurgy would already have exerted distinct ecological consequences.

For the past millennium, however, there is a tremendous iron production heritage in West Africa witnessing profound changes in societies and the economy going along with the general availability of iron. In many parts of West Africa, iron production remains are impressive and include enormous slag heaps, furnace remains, and sometimes complete smelting furnaces. The most intensive periods of iron smelting before its final demise in the course of the 20th century, are sometimes considered to have been of an industrial magnitude, leading to designations such as '19th century Ruhr' (Warnier and Fowler, 1979). Previous studies have discussed the severe ecological consequences of West African metallurgy (e.g., Haaland, 1980, 1985; Goucher, 1981, 1984; De Barros, 1986; Herbert and Goucher, 1987; Hahn, 1993, 1997; Thompson and Young, 1999; Pelzer et al., 2004). These studies assumed that the overexploitation of wood, as fuel for iron smelting furnaces, was linked to vegetation clearing ('deforestation') and soil erosion. Thus, deforestation was conveniently proposed as the fundamental cause of massive environmental degradation. However, most of these aforementioned studies lack anthracological analyses, which have the potential to detect presumed local vegetation changes.

Significant West and Central African Late Holocene environmental changes are indicated by numerous palynological, anthracological and sedimentological records (e.g. Salzmann and Waller, 1998; Salzmann et al., 2002; Lespez et al., 2011, Eichhorn and Neumann, 2013; Höhn and Neumann, 2012, 2016; Hubau et al., 2013, 2014; for a recent compilation of sites south of $10^{\circ} \mathrm{N}$ see Hubau et al., 2013: Fig. 5). However, the environmental effects of anthropogenic impact and climatic change are often difficult to separate out, and their relative importance are the matter of controversial discussions (e. g. Salzmann, 2000; Brncic et al., 2007; Bayon et al., 2012; Maley et al., 2012; Neumann et al., 2012; Lézine et al., 2013). The closest long term sequences which provide palaeoecological evidence for the period after 1000 AD, are Lac Sélé in Benin (Salzmann and Hoelzmann, 2005), Lake Bosumtwi in Ghana (e.g. Shanahan et al., 2008; Maley, 2004), Lake Tilla in Nigeria (Salzmann, 2000; Salzmann et al., 2002) and the Yamé River valley in Mali (Lespez et al., 2011). At Lake Bosumtwi, two lake level low-stands point to dry intervals at 850 and $250 \mathrm{BP}$ (Shannahan et al., 2008), whereas at Lac Sélé the predominance of savanna vegetation indicates generally drier conditions than before from 1050 BP onwards (Salzmann and Hoelzmann, 2005). At Lake Tilla, advanced silting up occurred during that period, subsequent to already increasing sedimentation rates after 2500 BP. The latter were discussed to be related to animal trampling, when the lake became an important water reservoir due to more arid climatic conditions (Salzmann et al., 2002). Soil erosion, as indicated by increasing sediment supply in the hydrosedimentary records of the Yamé River has been explained by the intensification of human impact during the past millennium (Lespez et al., 2011). Although they provide important evidence for increasing human impact under relatively arid conditions during the past millennium, conclusions on the local environmental impact of Bassar iron smelting, particularly on vegetation changes around the metallurgical sites, cannot be drawn from these studies.

Charcoal analysis can elucidate if past fuel choice for iron smelting was random or selective and investigate local-scale vegetation developments. Selective fuel choice for ironworking may lead to the possibility of overusing certain plant species, whereas, random choice and if at a low-level only, might remain without visible impact. Random choice at a high level overexploiting the entire woody stock may lead to distinct and general vegetation changes (summarized in Eichhorn, 2012; Eichhorn et al., 2013a, b).

Even if charcoal analyses reveal that vegetation changes occurred during periods of intensive metallurgy, such shifts might not be primarily due to wood use for iron smelting. Iron production is only one anthropogenic factor affecting woody vegetation during the West African Late Iron Age in the second millennium AD. Other factors include agricultural intensification coinciding with the strong expansion of agroforestry systems favoured by the now general availability of iron agricultural tools, the shortening of fallow cycles, and increased influence of herding linked to the arrival of pastoralist populations (Höhn and Neumann, 2012; Eichhorn and Neumann, 2013). These previous anthracological studies provide local to regional scale information on the factors impacting woody vegetation in the West African savanna and woodland zone in the Sahel and the northern Sudanian phytogeographic zones. The local impact of the Late Iron Age transformations in the West African Sudano-Guinean woodland areas further to the South with higher precipitation values and thus a probable higher ecological resilience remains to be deciphered with the help of further anthracological studies.

One of the major West African iron production centres is the Bassar region in Central Togo located around the town of the same name (Fig. 1). The onset of Bassar iron smelting is considered to date back to 200-400 BC (De Barros, 2012, 2013). This early evidence is followed by an apparent hiatus of a millennium (De Barros, 2013).

The introduction of induced draft furnaces (= natural draft furnaces) at the end of the 13th century $\mathrm{AD}$ resulted in major changes of Bassar iron production. Induced draft furnaces are ventilated through natural draft using tuyères without bellows and, thus, require less labour. This technology intensified production significantly and iron was traded to neighbouring West African societies (Martinelli, 1982; De Barros, 1985, 1986). From the 16th century onwards, production operated on a supra-regional scale. Production still expanded in the 19th century and eventually declined in the 20th century. De Barros (1986) thus proposed the division of the Bassar iron industry into four distinct periods: Period 1 (ca. late first millennium AD to 1300/1350 AD) was classified as small-scale production for mainly local needs; Period 2 (ca.1300/1350 AD to 1550/1600 AD) was categorised as significant local production; Period 3 (ca. 1550/1600 AD to ca.1800 AD) witnessed large-scale production for supra-regional export; and, Period 4 (ca. 1800 AD to 1905 AD and 1925 AD in the eastern and western parts of the research area, respectively) was characterised by expanding production, disruption, and the eventual decline of Bassar iron metallurgy.

Before our interdisciplinary investigations presented in this paper, the area has been the subject of previous intensive archaeological, ethno-archaeological and historical research (e.g., Goucher, 1981, 1984; Martinelli, 1982, 1984, 1992; De Barros, 1985, 1986, 2012, 2013; Dugast, 1986, 2004, 2012; Herbert and Goucher, 1987; Hahn, 1993, 1997). In this context, the ecological impacts of Bassar iron smelting, particularly vegetation degradation due to wood consumption, were repeatedly discussed. However, similar to most other West African iron production centres, anthracological investigations have been missing. Therefore, the systematic retrieval of wood charcoal samples from waste heaps and furnace remains followed by wood charcoal analyses have been an integral part of our recent interdisciplinary research in the Bassar area. These analyses aimed at understanding wood use for iron smelting and deciphering possible changes in wood exploitation through time, which might point to vegetation changes.

In our previous studies on the ecological consequences of intensive iron production in areas further to the north, specifically 


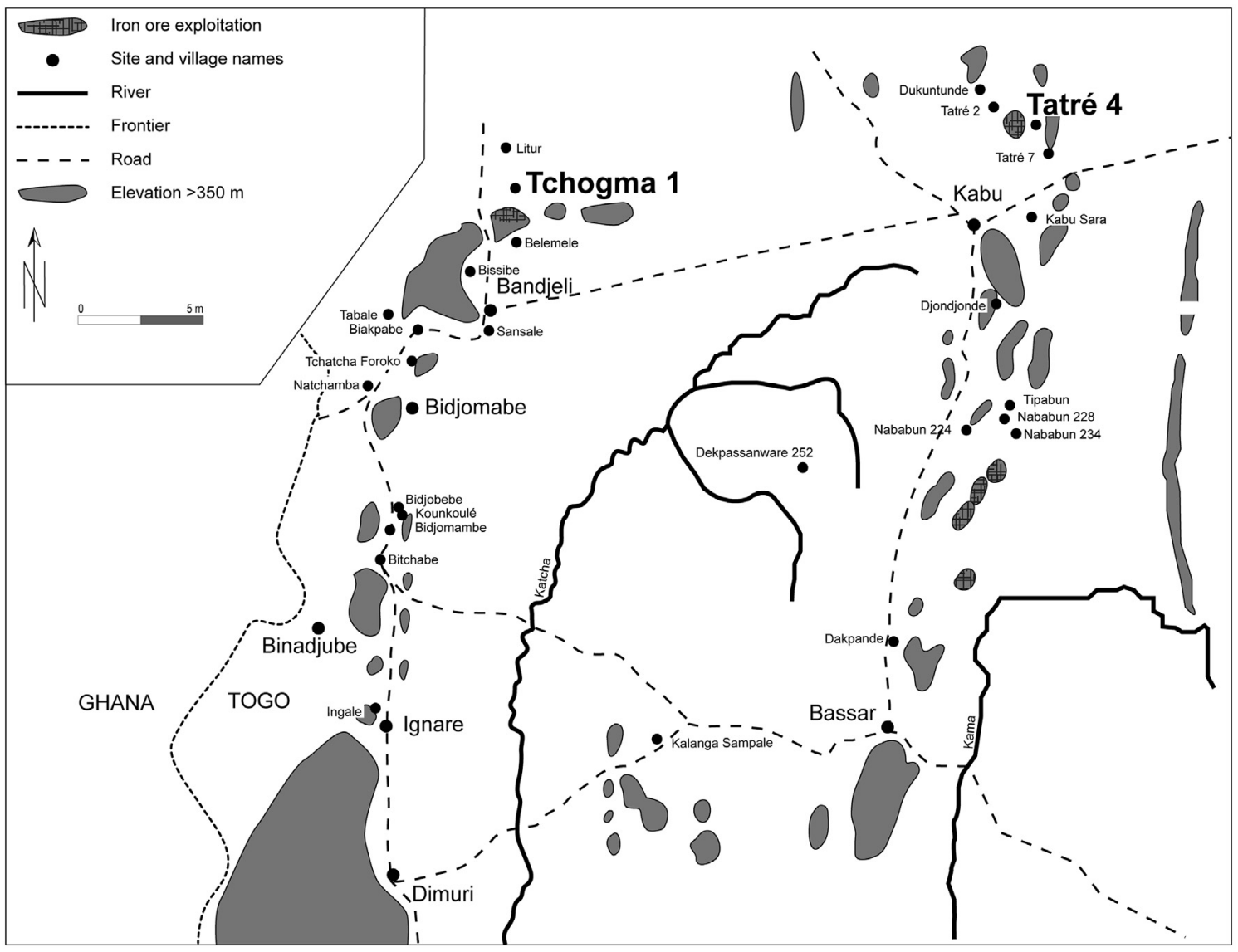

Fig. 1. Map of the research area with selected smelting sites and villages, investigated sites in bold letters (based on De Barros, 1986; modified).

in the Dogon Country in Mali, wood charcoal sequences were established on charcoal retrieved from iron smelting waste heaps (Eichhorn, 2012; Eichhorn et al., 2013 a,b). These slag heaps are part of metallurgical site complexes of the Fiko tradition on the western margin of the Dogon Plateau. Distinct surplus production is evidenced for the Fiko tradition operating for at least during 900 years and only ceasing in the early 20th century AD. Site locations and production levels far exceeded local needs, thus, the produced iron was distributed outside the Dogon Country, presumably in the Inland Niger Delta (Robion-Brunner et al., 2013). Anthracological analyses at these sites have indicated distinct vegetation changes in the course of occupation (Eichhorn, 2012; Eichhorn et al., 2013a a,b). However, as explained earlier, vegetation changes observed in charcoal analyses at ironworking sites should not be automatically linked to the presumed impact of woody resource exploitation for smelting because various other factors might be causing these changes. Wood use can be sustainable as long as the exploited biomass does not exceed re-growth in the period of exploitation (Von Maltitz and Scholes, 1995). Conversely, harvesting wood for fuel in a manner that exceeds the regenerated amount of wood is unsustainable and leads to changes in the structure and composition of the vegetation (Luoga et al., 2002). Therefore, at the Fiko tradition sites, we combined the anthracological investigations with a quantitative approach in order to test whether wood use for iron metallurgy was at a sustainable or unsustainable level. We estimated the annual wood exploitation for iron smelting based on slag-charcoal-wood conversion ratios in comparison with data on annual wood reproduction (the latter based on Clément, 1982). At these high production level sites in Mali, the results of this quantitative approach have effectively pointed to an operation of iron smelting at the ecological threshold, thus, in this case, indicating a link between the observed local vegetation changes and metallurgy. Tree growth in woodlands is influenced by numerous factors, including water availability, fire, tree-grass and/or tree-tree competition, herbivory, carbon dioxide concentration, temperature, and soil fertility (summarized in Baudena et al., 2015). Despite this complexity, classical studies on wood biomass productivity in West African savannas have shown that annual wood mass reproduction is positively correlated to average annual precipitation (Clément, 1982; Keita, 1982; Breman and Kessler, 1995: 60 onwards). While the Fiko area is situated in the northern Sudanian phytogeographic zone receiving about 500-600 mm annual precipitation, Bassar is situated further to the South in the southern Sudanian phytogeographic zone with 1200-1400 mm annual precipitation (Gu-Konù, 1981a; Kouami et al., 2009; De Barros, 2013). Therefore, we expect wood biomass regeneration to be distinctly higher in the Bassar area than in central Mali. Moreover, annual slag output (based on De Barros, 1986) has been estimated to have been much lower in Bassar than in Fiko and the available surface for wood exploitation is much vaster. This led us to our initial hypothesis, presented in a previous publication, that it is unlikely that Bassar iron metallurgy could have caused massive vegetation degradation (Eichhorn et al., 2013b), an opinion also previously expressed by ecologists (Fairhead and Leach, 1998).

With our current study presented here we have aimed to test this hypothesis through anthracological investigations at Bassar in order to:

a) detect possible vegetation changes coinciding with high intensity iron smelting at Bassar; and, 
b) provide evidence of either random fuel choice or conscious species selection for a specialised technique which requires high temperatures which, as stated above, may influence woody vegetation in different ways.

Therefore, this article presents the results of charcoal analyses from the two most important metallurgical site complexes in the Bassar area, Tchogma and Tatré. Tchogma is situated in the northwest region of the research area and is close to the present-day village of Belemele. In Belemele, the last smelts are still remembered by a few last eyewitnesses who can give detailed reports on wood selection for the iron smelting process. The smelting site is located between two hills north of the Tchogma Mountain and in the vicinity of an abandoned village site (the precursor to the present Belemele settlement), which is reported to have had an associated iron market on one of the hills. Tatré is situated in the northeast and in the valley of the seasonal Tatre River, north of the town of Kabou. Today this is a remote area where the small current Fulbe population arrived only after the abandonment of iron smelting.

In the course of this study, we investigated wood use as fuel for iron smelting in the project study area and attempted to establish charcoal sequences for evaluating possible changes in wood exploitation through time. Such changes might reflect vegetation changes in the vicinity of the sites. To this end, charcoal samples were systematically retrieved from metallurgical waste heaps for charcoal analyses during small-scale excavations and an attempt was made to establish a chronology for the two sites through radiocarbon dating. Oral traditions, recorded through interviews, provided supplemental ethnohistorical data. This method was developed and successfully applied in previous studies (RobionBrunner, 2010; Eichhorn, 2012; Eichhorn et al., 2013a,b). Slag accumulation as the basic proxy of fuel wood use intensity was reevaluated by refining waste heap topographical measurements with tacheometry and by conducting slag mass per volume measurements absent from earlier studies in the Bassar area.

\section{Research area}

The Bassar area is situated at the transition of Sudanian savannas and dry forests in the Southern Sudanian vegetation zone (Brunel, 1981). The climate is distinctly seasonal, with a rainy season lasting from April to October and a dry season from October to March. The area receives $1200-1400 \mathrm{~mm}$ of precipitation annually (Gu-Konù, 1981a; Kouami et al., 2009; De Barros, 2013). It is located in the hill zone of Togo, the north-western foothills of the Atakora Mountains, which is, close to the town Bassar, characterized by isolated steep massifs (Petit, 1981). The iron ore deposits of the hills have been estimated to 550 million tons (Seddoh, 1981).

Vegetation on the plains has been strongly transformed by human impact and consists mainly of agroforestry parklands made up of fields and fallows of protected fruit trees - particularly the shea butter tree (Vitellaria paradoxa) and the néré tree (Parkia biglobosa) - and the re-growth of trees and shrubs which were cut when preparing the fields. Traditionally, small house fields and gardens are cultivated permanently and fertilized with dung. In the distant bush fields, shifting cultivation with fallow periods of $10-15$ years in order to regenerate unfertilized soils is practiced (Martinelli, 1984). The most important crops are yams and sorghum (GuKonù, 1981b; Martinelli, 1984) with a number of local varieties, followed by pearl millet. Other legumes and vegetables are cultivated on a smaller scale. Today, cotton is planted as a cash crop and manioc has partly replaced yams (own observations, 2014).

The cultivation of yams is a laborious task and practiced in small raised mounds supported by tree stumps (Martinelli, 1984: Photo
6). The preparation of these mounds, as well as their destruction when harvesting the tubers, is traditionally associated with the use of a special iron hoe, only used by men, in the Bassar area (Martinelli, 1984), a fact which illustrates the importance and the specialisation of iron agricultural tools.

The steep hill slopes are not cultivated, but grazed by domestic stock and, when close to settlements, are subject to intensive wood cutting for various domestic purposes. Here, they are often dominated by vigorously re-sprouting species such as Pericopsis laxiflora and Isoberlinia spp. Intentional bushfires are practiced and this favours the survival of fire-resistant taxa in the long run (see Ballouche and Dolidon, 2005; Eichhorn and Neumann, 2013). The Bassar area, thus, constitutes a typical Sudanian cultural landscape composed of a small-scale mosaic of fields, fallows of different ages, savannas, and rare small dry gallery forest patches that are mainly restricted to sites unsuitable for cultivation (Neumann et al., 2004).

\section{Site characteristics}

The investigated Bassar iron smelting sites are often very complex and made up of a high number of working areas (sectors). These sectors are entities of metallurgical waste and furnace remains which were once operated contemporaneously.

The site complex of Tchogma covers an area of about $56,000 \mathrm{~m}^{2}$ and contains 170 slag heaps and 130 still-discernible furnaces. The slag heaps, made up of tapped fayalitic slags and siliceous plattershaped slags in approximately equal parts, are up to $3 \mathrm{~m}$ high and occur mainly in groups of two to three with younger heaps occasionally overlapping older ones. The highest and steepest heaps are situated in the northeastern part of the site complex, whereas, the southern part is characterized by smaller and more extended heaps. To the west, the extension of the site is limited by the hill's foot-slope. Archaeological and archaeometallurgical methods at Tchogma 1 were the same as Tatré 4, described below.

The site complex of Tatré consists of several varying-sized sites distributed in the upper and middle Tatré River Valley. Small sites are made up of one to a few isolated slag heaps, e.g., Tatré 4-5 is made up of three slag heaps in the vicinity of Tatré 4 , whereas, larger sites, such as the newly discovered site Tatré 7 , may be made up of more than 200 waste heaps.

In the course of our investigations presented here, Tatré 4, an individual site of the Tatré site complex on the left river bank, has intensively been archaeologically and archaeometallurgically studied. Investigations included, precise topographical measurement of all heaps with tacheometry, systematic slag mass/volume measurements to re-evaluate earlier data on slag amount and iron output, and systematic charcoal sampling for radiocarbon dating and anthracological analyses. The site covers an area of around 15 ha and contains 139 metallurgical waste heaps. These heaps have a total surface of about 0.5 ha and evidence 57 furnace remnants. Fig. 2 illustrates the spatial organisation of Tatré 4, showing the distribution of the furnace remains and different slag accumulations, the location of excavation pits and trenches, and available radiocarbon dates (cal. AD, 95\% probability, calibration curve Reimer et al., 2013) are sketched in.

\section{Site chronology}

\subsection{Tchogma}

During earlier investigations by Philip de Barros, iron metallurgy at Tchogma 1 was dated to between the 16 th and $18 \mathrm{t}^{\mathrm{h}}$ century with the help of two radiocarbon dates (1530-1633 AD; 1510-1800 AD, modified after De Barros, 1986: Table 1). Tchogma was thus attributed to period 3 of iron Bassar iron production history. One of 


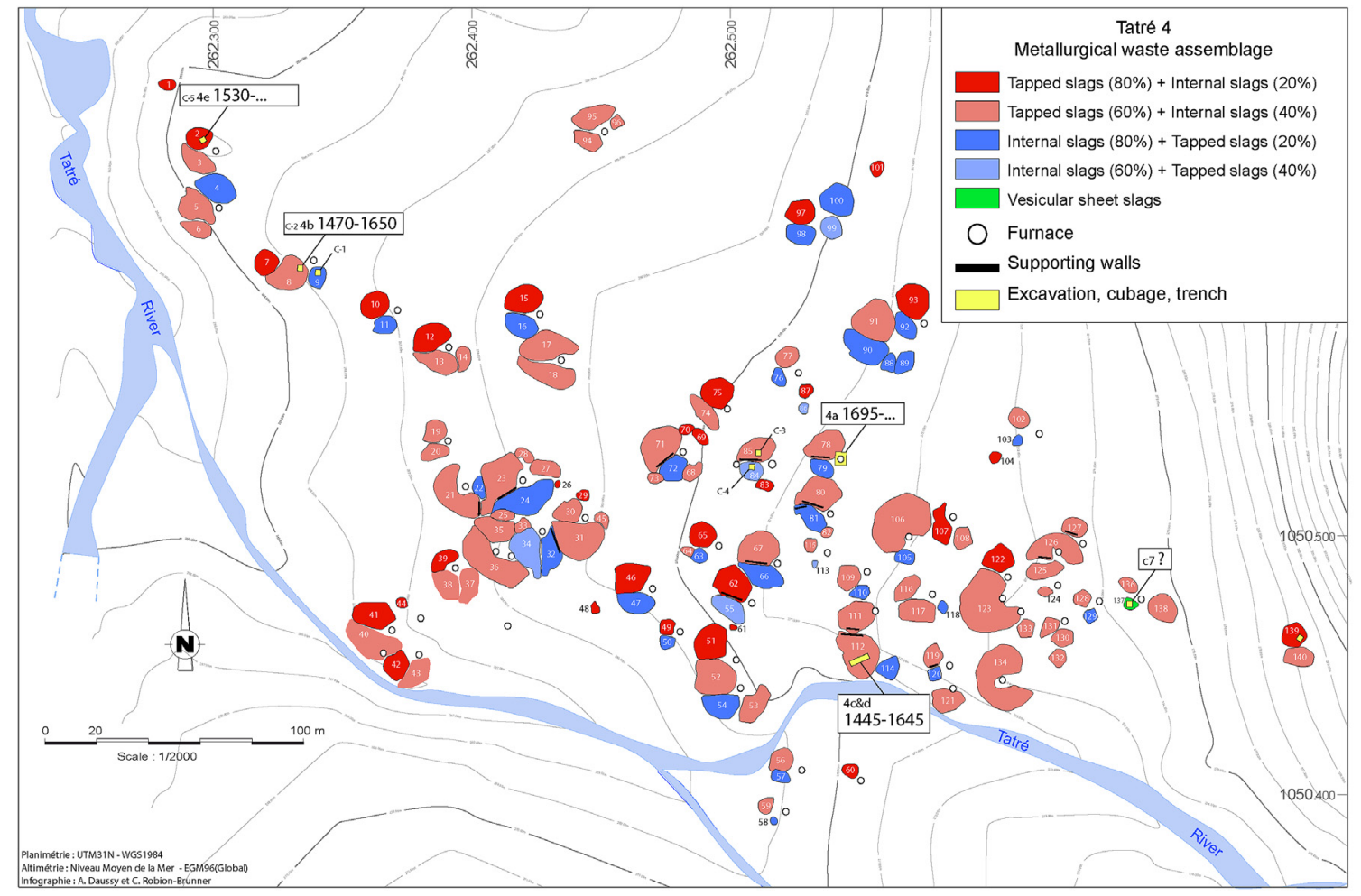

Fig. 2. Plan of the site Tatré 4 , indicating the distribution of slag heaps, furnace remains, slag type distribution, excavations and calibrated radiocarbon dates.

Table 1

Radiocarbon dates for Tchogma and Tatré obtained during this study (cubage = excavation with slag mass per volume measurements, see Materials and methods).

\begin{tabular}{|c|c|c|c|c|c|c|c|}
\hline Site Name & $\begin{array}{l}\text { Cubage Trench } \\
\text { Furnace }\end{array}$ & Heap & $\begin{array}{l}\text { Dating Sample } \\
\text { Name }\end{array}$ & $\begin{array}{l}\text { Laboratory } \\
\text { Number }\end{array}$ & $\begin{array}{l}\text { Conventional } \\
\text { Radiocarbon Age }\end{array}$ & $\begin{array}{l}\text { Age cal AD } \\
\text { (95\% probability) }\end{array}$ & $\begin{array}{l}\text { Iron production period } \\
\text { (established by De Barros, 1985) }\end{array}$ \\
\hline Tatré 4-5 & & $3,-80 /-100 \mathrm{~cm}$ & Tatré 4-5 & Beta-421729 & $640 \pm 30 \mathrm{BP}$ & $1285-1395$ & Period 1 \\
\hline Tatré 4-5 & & $3,-20 /-40 \mathrm{~cm}$ & Tatré 4-5b & Beta-433413 & $710 \pm 30 \mathrm{BP}$ & $1265-1380$ & Period 1 \\
\hline Tatré 4 & C 2 & 8 & Tatré 4b & Beta-385468 & $320 \pm 30 \mathrm{BP}$ & $1470-1650$ & Period 2 \\
\hline \multirow[t]{2}{*}{ Tatré 4} & T 1 & 112 & Tatré $4 \mathrm{c}$ & Beta-414106 & $330 \pm 30 \mathrm{BP}$ & $1465-1645$ 1445-1635 & Period 2 \\
\hline & & & Tatré 4d & Beta-414107 & $370 \pm 30 \mathrm{BP}$ & & \\
\hline Tatré 4 & C 5 & 2 & Tatré $4 \mathrm{e}$ & Beta-414108 & $250 \pm 30 \mathrm{BP}$ & $1530-1950$ & Period 3 and 4 \\
\hline Tatré 4 & F 33 & & Tatré 4a & Beta-385467 & $60 \pm 30 \mathrm{BP}$ & 1695-post 1950 & Period 4 \\
\hline Tchogma 1 & & b 2 & Tchogma 1b2 & Beta-421730 & $80 \pm 30 \mathrm{BP}$ & 1685-post 1950 & Period 4 \\
\hline
\end{tabular}

the heaps excavated in 2015 yielded a radiocarbon date (1695-post $1950 \mathrm{AD}$ ), possibly pointing to later production continuation until recent times. As radiocarbon dating does not yield reliable dates for the last 300 years this remains, however insecure. Iron-working at Tchogma until memorable times is also indicated by oral traditions. Charcoal assemblages were analysed from both sectors (sector 2: heap 1; sector 39: zone close to the furnace).

\subsection{Tatré}

At Tatré, early iron production dating back to the end of period 1 , around the 13th century AD, is evidenced for Tatré 4-5 (Table 1) and for Tatré 2 (previously investigated and dated by De Barros, 1986; not treated here). At Tatré 4, iron smelting activities appear to have started contemporaneously in the eastern part of the site, around heap 137. The contemporaneousness is indicated by the presence of archaeometallurgical remains that prove the application of the same metallurgical technology as at Tatré 4-5 and Tatré 2 . The peak activity at Tatré 4 took place between 1450 and 1700. Production continued at lower levels during the 18th and the early 19th centuries before the site was abandoned as indicated by oral traditions.

\section{Material and methods}

At both site complexes, select slag heaps were chosen for excavation. Several $1 \mathrm{~m}$ x $1 \mathrm{~m}$ squares were opened and recorded by demarcating artificial spits of depths between 20 and $50 \mathrm{~cm}$ (depending on the nature of the excavated sediments). Total excavation depth varied amongst heaps and excavation ceased when sterile material without archaeometallurgical material and charcoal was reached. At Tatré 4, a larger excavation trench of $4 \mathrm{~m} \times 1 \mathrm{~m}$ was dug in heap 112 , going down to a depth of $2.3 \mathrm{~m}$.

At a number of trenches at both site complexes, slag mass per volume measurements were conducted using the 'cubage' method. During a cubage, a known volume within a metallurgical site is excavated, e.g., a cube with $50 \mathrm{~cm}$ side lengths. The different materials contained in this volume, such as furnace wall debris, tuyères and slags are separated. Subsequently, every material is weighed separately with a balance. The resulting mass/per volume number is extrapolated to a standard volume. In order to respect differences in the sediment composition, the entire process should be repeated (Robion-Brunner and Serneels, 2017). At Tchogma, seven cubages and at Tatré six cubages were conducted. 
Wood charcoal samples were retrieved by dry-sieving the sediment of the metallurgical waste heaps after removal of coarse and heavy materials such as large pieces of furnace wall remains, tuyère fragments, and slag pieces in order to avoid destruction of the charcoal fragments during the process. Wet sieving was not performed in order to prevent hyper-fragmentation of dry and brittle charcoal that could occur when coming in contact with water. All fragments large enough to securely provide enough anatomical features to enable botanical identification criteria $(\geq 2.5 \mathrm{~mm}$ ) were collected from the sieves.

Prior to analysis, all charcoal fragments were split into the three diagnostic planes transverse, tangential, and radial. Splitting in the longitudinal planes (i.e., tangential and radial) took place with the help of a razor blade, whereas, transverse plane fragments were broken by hand. Subsequently the fragments were placed in sterile sea sand and studied with a Laborlux $S$ incident light microscope (range of magnifications: $62,5 \mathrm{x}-625 \times$ ).

Identifications followed the International Association of Wood Anatomists (IAWA) standards (IAWA Committee, 1989) using the slide reference collection of modern African woods in the Frankfurt Archaeological Institute at the Goethe University, wood anatomical atlases, anthracological catalogues (Neumann et al., 2001; Eichhorn, 2004; Höhn, 2005), and the InsideWood internet database (InsideWood, 2004 onwards).

Similar to Ekblom et al. (2014), we applied the type concept for identification, which uses a type to represent a morphological or, in the case of wood charcoal, an anatomical category that is distinguished from others by a single character or a significant character combination. A type may, thus, represent one or, more often, several species (cf. Punt et al., 2003: 1). In tropical African anthracology, such conceptual types are necessary as wood anatomy does not, in most cases, allow for an unambiguous species determination, thus, several taxa with similar wood anatomical structure have to be grouped together (Ekblom et al., 2014; Hubau et al., 2012; Höhn and Neumann, accepted). An attribution to existing woody taxa and archaeobotanical interpretation should follow in subsequent steps afterwards (Höhn and Neumann, accepted). Documentation of the delineated charcoal types were conducted either with a Hitachi SEM or with a Leica DM 400 M incident light microscope equipped with a Leica DFC 295 digital camera containing motorised focus and the Leica LAS imaging software. Through stacking, the latter equipment allows reducing the differences in the depth of field caused by the uneven surfaces of broken wood charcoal. This method does not allow for the documentation of minute anatomical characters, such as vestured pits, and its image processing capacities often lead to a blurred appearance of cell wall edges and boundaries.

In order to supplement the archaeobotanical investigations with historical data on wood use for iron smelting, interviews in the villages of Belemele, Bissibe and Tabale where the last smelting processes are still remembered in detail by the local population were conducted (Fig. 1, north-western part of the Bassar region, near the Tchogma site complex). Due to the old age of the interviewees, this knowledge is in danger of becoming lost. In the northeast of the Bassar region, close to the site complex of Tatré, there is unfortunately no detailed memory of wood use for iron smelting as the current local Fulbe population only arrived there after the abandonment of this technology.

The five interviewees (three persons at Bissibe, one person at Belemele, and one at Tabalé) who had witnessed iron smelting when they were younger were asked to report in detail how the smelting furnaces were constructed and filled and which woody plant species were used as fuel for iron smelting. For botanical identification of the taxa, the interviewees were asked to bring identifiable branches, and whenever possible with flowers and fruits, of all mentioned trees and shrubs. Identification took place in the field with the help of botanical literature (Hepper, 1954-1972; Arbonnier, 2002). In addition, the local plant names were noted. Detailed photos were taken of the specimens and archived in the West African Plant Database (Brunken et al., 2008 onwards).

At the specialised charcoal manufacturing site of Dimuri (Fig. 1) the two interviewees, a very old woman, who was involved with the production of charcoal when she was younger, and an elderly man, formerly engaged in the business of selling the charcoal, were asked to describe which species were exploited for charcoal, how the wood for the charcoal fabrication was collected (felling of whole trees vs. cutting branches), and if differences in regeneration after cutting were recognised in different tree species.

\section{Results}

\subsection{Wood charcoal analysis}

All analysed charcoal samples, regardless of site and production period, are dominated by only a few charcoal types, representing a restricted number of woody taxa (Figs. 3 and 4, wood anatomical descriptions of the charcoal types and differential diagnosis see Appendix). The Prosopis africana type (Fig. 5), Pericopsis spp. (Fig. 6), Caesalpinioideae undifferentiated, and the Sapotaceae type (Fig. 7) are ubiquitous and with the highest relative frequencies. The Prosopis africana type probably consists of a single species, Prosopis africana, which is a Sudano-Guinean savanna tree that is highly valued by blacksmiths and metallurgists in many parts of West Africa (e.g., Burkill, 1985-2000; Arbonnier, 2002; Kiethéga, 2009: 249-257). The Sapotaceae type probably represents the shea butter tree Vitellaria paradoxa, one of the most dominant constituents of the regional agroforestry parklands (own observations, 2014; Wala et al., 2005). Wood anatomical differentiation from other Sapotaceae taxa occurring in the southern Sudanian zone is problematic; however, vessel arrangement, parenchyma distribution, and no observation of silica bodies point to Vitellaria paradoxa (Fig. 7) see below for differential diagnosis). In Burkina Faso, the shea butter tree is most often mentioned as being suitable for iron smelting fuel and its wood is among the most important firewoods in the southeastern Burkina Faso (Kiéthéga, 2009: 249-257; Gallagher, 2010: Table 3.5). Its use for iron smelting in Bassar is also consistent with our observations in Mali, where this species has been regularly used for the same purpose (Eichhorn, 2012; Eichhorn et al., 2013a,b; Eichhorn and Neumann, 2013). Pericopsis spp. (in the research area this wood anatomical type is only represented by the species $P$. laxiflora) and Caesalpinioideae undifferentiated have also been identified in iron smelting sites in the northern Ivory Coast (Serneels et al., 2016). Pericopsis laxiflora wood makes excellent charcoal (Burkill, 1985-2000). This species occurs in savannas, edges of gallery forest, and in fallows (Arbonnier, 2002). In Bassar, it is a vigorously re-sprouting shrub or small tree on fallows and on hill feet subjected to wood-cutting (own observations, 2014). The type Caesalpinioideae undifferentiated is comprised of a number of species which cannot be distinguished on the basis of their wood anatomy. This type also comprises Burkea africana, which is, according to the ethnohistorical interviews, one of the trees yielding highly estimated fuel for iron smelting in Bassar. B. africana is a Sudano-Guinean savanna tree whose wood is exploited for firewood and charcoal, the latter the preferred fuel used by blacksmiths in various African regions (Arbonnier, 2002; Burkill, 1985-2000).

Other taxa are also represented in the charcoal assemblages, but less common and mostly with lower percentages. The wood anatomical types Terminalia spp., Detarium spp. (including D. microcarpum and $D$. senegalense) as well as Chrysobalanaceae 


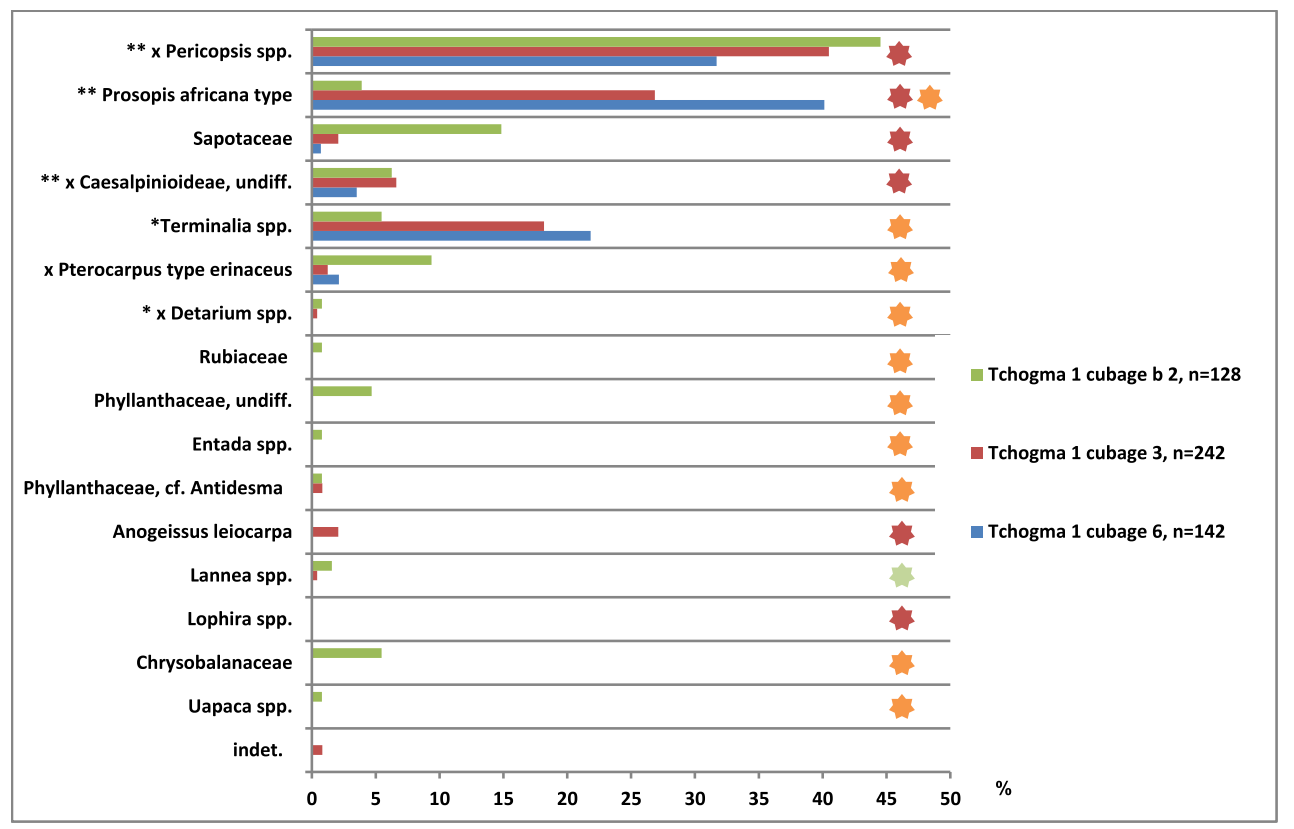

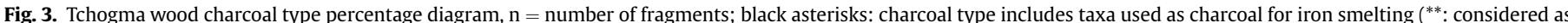

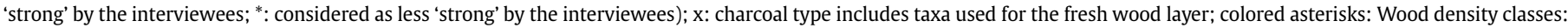

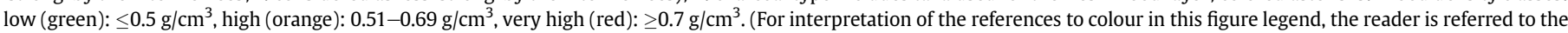
web version of this article.)

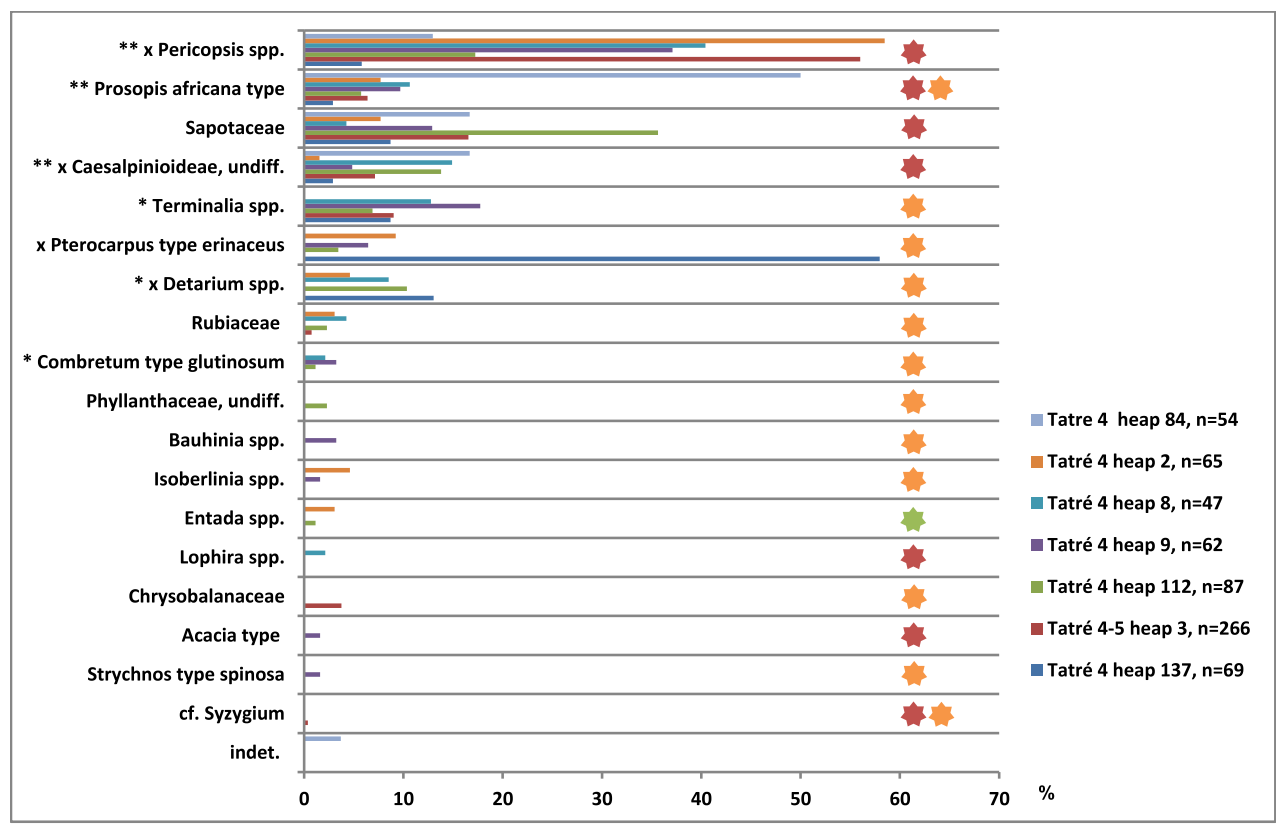

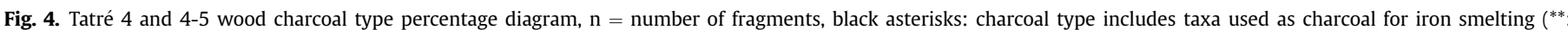

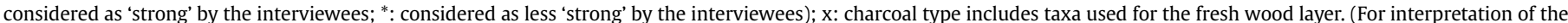
references to colour in this figure legend, the reader is referred to the web version of this article.)

represent, in each case, at least two or more often a number of woody species with variable ecological requirements, a fact that impedes an ecological interpretation of the charcoal assemblages in these cases. Terminalia macroptera occurs in wet lowland savannas on clayey soils, whereas, the species Terminalia avicennoides occurs predominantly on sandy soils in savannas, dry forests, and fallows (Arbonnier, 2002). The type Detarium spp. comprises at least two species, Detarium microcarpum and $D$. senegalense. D. senegalense is a lowland dry forest and gallery forest species in savanna areas, often found along watercourses (El-Kamali, 2011). In Bassar, D. microcarpum is a very common species on older fallows and on hill feet that are regularly exposed to bush fires. This is also the case for Pterocarpus erinaceus and Entada africana. The taxa Combretum glutinosum, Terminalia spp. and Bauhinia spp. (including Bauhinia reticulata and Bauhinia thonningii) are fallow species of the area with a high capability to re-sprout. Isoberlinia spp. (Fig. 8). are 

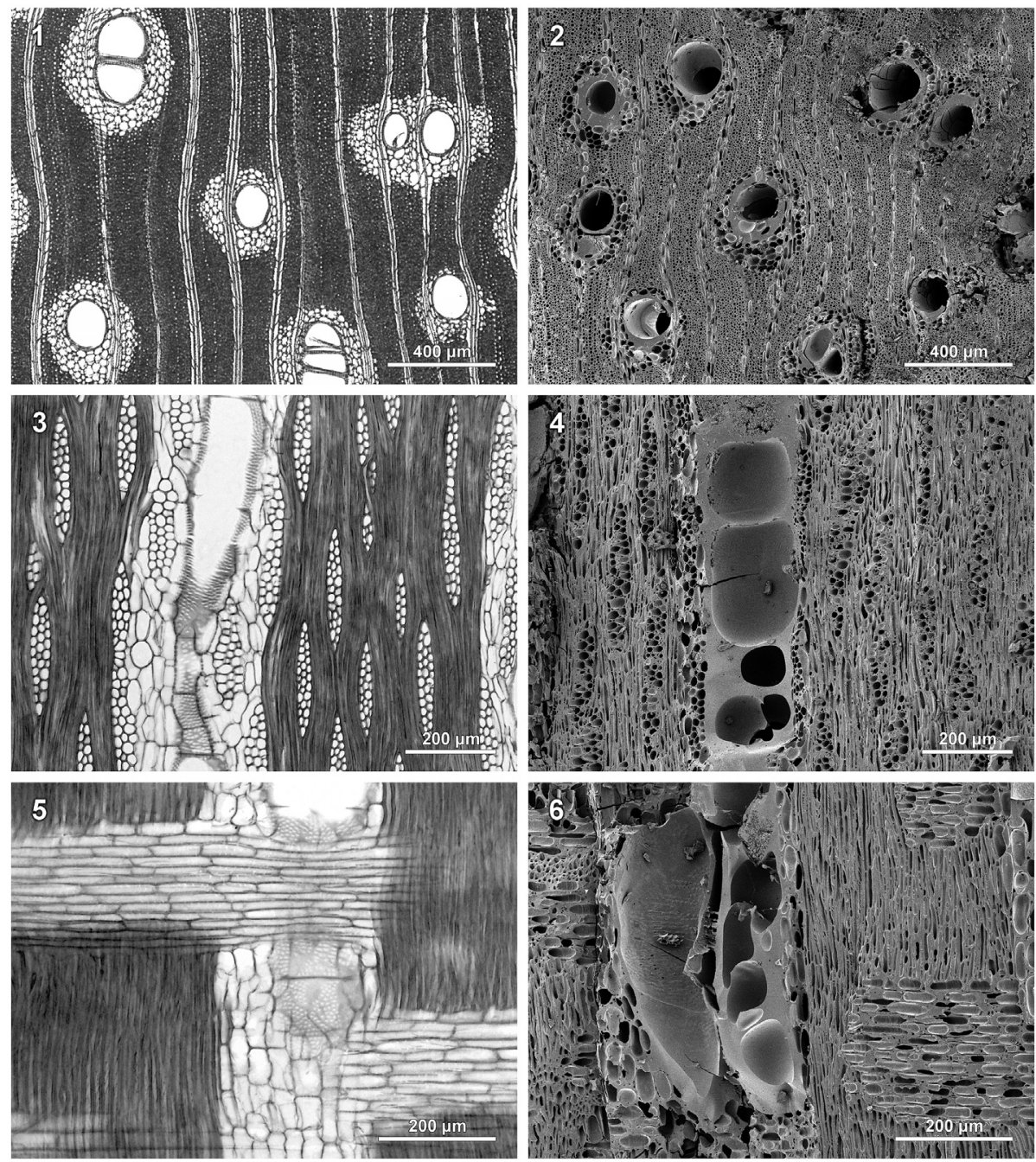

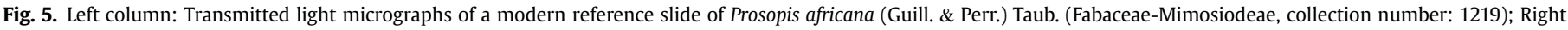
column: Scanning Electron Micrographs of charcoal type Prosopis africana type. 1-2: Transversal view; 3-4: Tangential view; 5-6: Radial view.

vigorously resprouting species on the Bassar hill sites (own observations, 2014). Lophira lanceolata is considered an invasive species recolonising fallows at forest edges (Arbonnier, 2002). According to local informants, this species is often in its sterile state confounded with the shea butter tree. Therefore, it is called "false shea butter" and often overlooked when weeding regrowth in bush fields.

The dominant charcoal types, as well as most of the less frequent ones, represent woody taxa with a high wood density (Table 2, also see Eichhorn et al., 2013 a,b). Taxa with a low wood density ( $\leq$ the mean calculated for tropical African woods in Reyes et al., 1992: Fig. 1), such as Ficus spp., Bombacaceae (Bombax costatum, Adansonia digitata) or Sterculia setigera, are absent from the charcoal spectra, though definitely not rare in the area (own observations, 2014). Bombax costatum is a fire-resistant tree with multiple uses (Burkill, 1985-2000; Maydell, 1990), which is quite common in the Bassar area, in savannas and close to settlements. The only exceptions of the high wood density rule are a few fragments of Lannea spp. at Tchogma.

A few taxa in the Bassar iron smelting assemblages are either restricted to one site or to a single slag heap within one of the sites. For example, Anogeissus leiocarpa is extremely rare in the Bassar area and restricted availability might be the reason for the low abundance and frequency in the charcoal assemblages. During interviews on charcoal use of current and past blacksmithing in
Bassar, the interviewees mentioned the high quality of Anogeissus leiocarpa, but stated that its wood is barely used due to the scarcity of the tree in the area.

Most taxa represented in the charcoal assemblages currently have a wide-spread occurrence in agroforestry parklands. They are either useful species protected from felling when preparing fields, or fallow taxa which are able to re-sprout after cutting when fields are temporarily abandoned in order to restore soil fertility, or they occur in steep hilly areas not suitable for cultivation but for wood procurement. Among the important taxa, Prosopis africana is virtually an exception from this rule as this species is mainly restricted to little disturbed savanna vegetation and reported to regenerate poorly after cutting (see below in interviews on wood use).

Except for the presence of the type Phyllanthaceae cf. Antidesma and one poorly preserved fragment of cf. Syzygium, there is little unequivocal evidence for the exploitation of gallery forest occurring along seasonal rivers. Other members of the Phyllanthaceae and Rubiaceae families also occur in gallery forests, but the uniform wood anatomy of these taxa does not allow for secure differentiation between savanna or fallow species and the wetland species within these families. Common taxa of gallery forests in the area, such as Khaya senegalensis, are not represented in the charcoal of Tatré or Tchogma, despite the proximity of Tatré to the temporal 

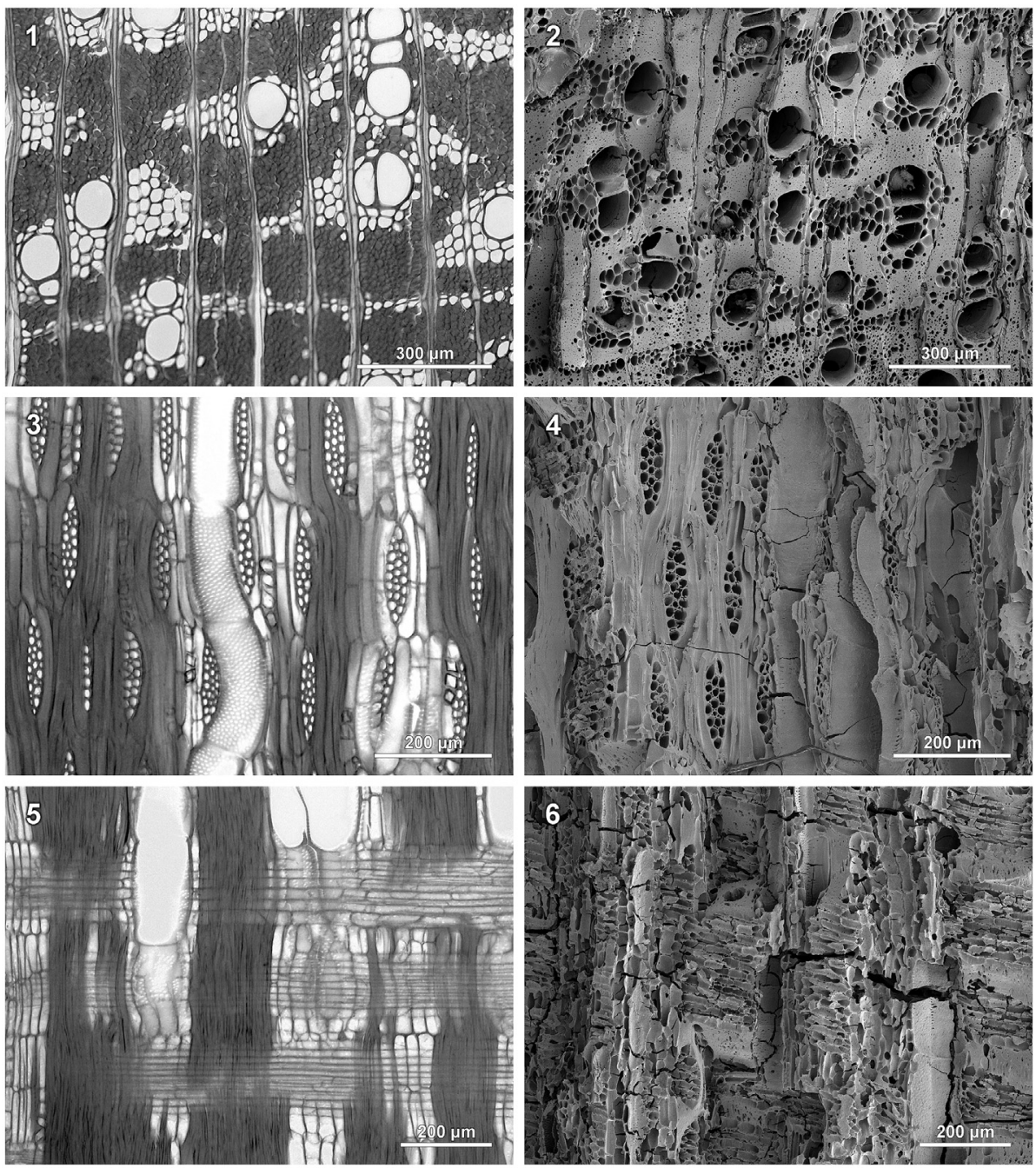

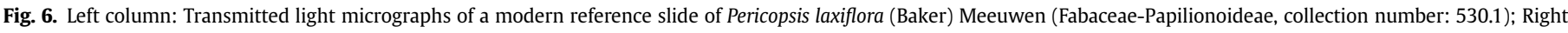
column: Scanning Electron Micrographs of charcoal type Pericopsis spp. 1-2: Transversal view; 3-4: Tangential view; 5-6: Radial view.

river course of the same name.

Concerning the relative proportions of the dominant charcoal types, there are some distinct variations between the different slag heaps. This is particularly evident at Tchogma where Prosopis africana type is much less represented in cubage b2, whereas, the Sapotaceae type and Pericopsis spp. are better represented than in the other heaps. A displacement of Prosopis africana from the local woody vegetation in the course of time might be indicated, as well as its replacement by agroforestry parkland species, specifically, taxa with the ability to re-sprout. Several factors, possibly including overuse of Prosopis africana for metallurgy, might be responsible, but also the expansion of cultivated areas. Unfortunately, it is uncertain whether cubage b2 is definitely younger than the other heaps as radiocarbon dating is not reliable for the past 300 years.

\subsection{Interviews on wood use}

The ethnohistorical interviews on wood use for the iron smelting process revealed both general trends as well as local differences in the three villages of Belemele, Bissibe and Tabale (Table 3). The five interviewees agreed upon the fact that the three species, Prosopis africana, Pericopsis laxiflora and Burkea africana, were the most important trees to make charcoal for iron smelting. All persons reported that, in addition to the charcoal fuel poured in alternating layers with the ore, a layer of fresh wood had to be added when filling the furnace. This method of filling the smelting furnace and the possible benefit of adding a fresh wood layer has also been described and discussed by Hahn for Bandjeli (1993: 109-112). According to his explanations, the heating of fresh wood leads to the emission of methane and other hydrocarbons, and, subsequently, these gases burn to carbon dioxide and water. This reaction is highly reductive and at temperatures above $720^{\circ} \mathrm{C}$, oxygen is, thus, extracted from the iron ore.

In Belemele, no other tree species were mentioned to be a good source of wood for iron smelting charcoal and only Pericopsis laxiflora was considered useful as supplementary fresh wood. In contrast, the interviewees in Bissibe and Tabale mentioned further tree species to be valuable and differentiated between 'strong' and 'less strong' sources of charcoal for iron smelting. They consider both fuel qualities, 'strong' and 'less strong' filled into the furnace in alternating layers, as important for the iron smelting process. Concerning the fresh wood layer, Afzelia africana was preferred in Bissibe, whereas, a number of species were used in Tabale.

All trees considered as 'strong' are members of the Fabaceae family, whereas, all those considered as 'less strong' belong to either the Combretaceae family or to the Fabaceae (Detarium microcarpum). In fact, according to all interviewees, only members of these two plant families yielded suitable fuel for past iron 

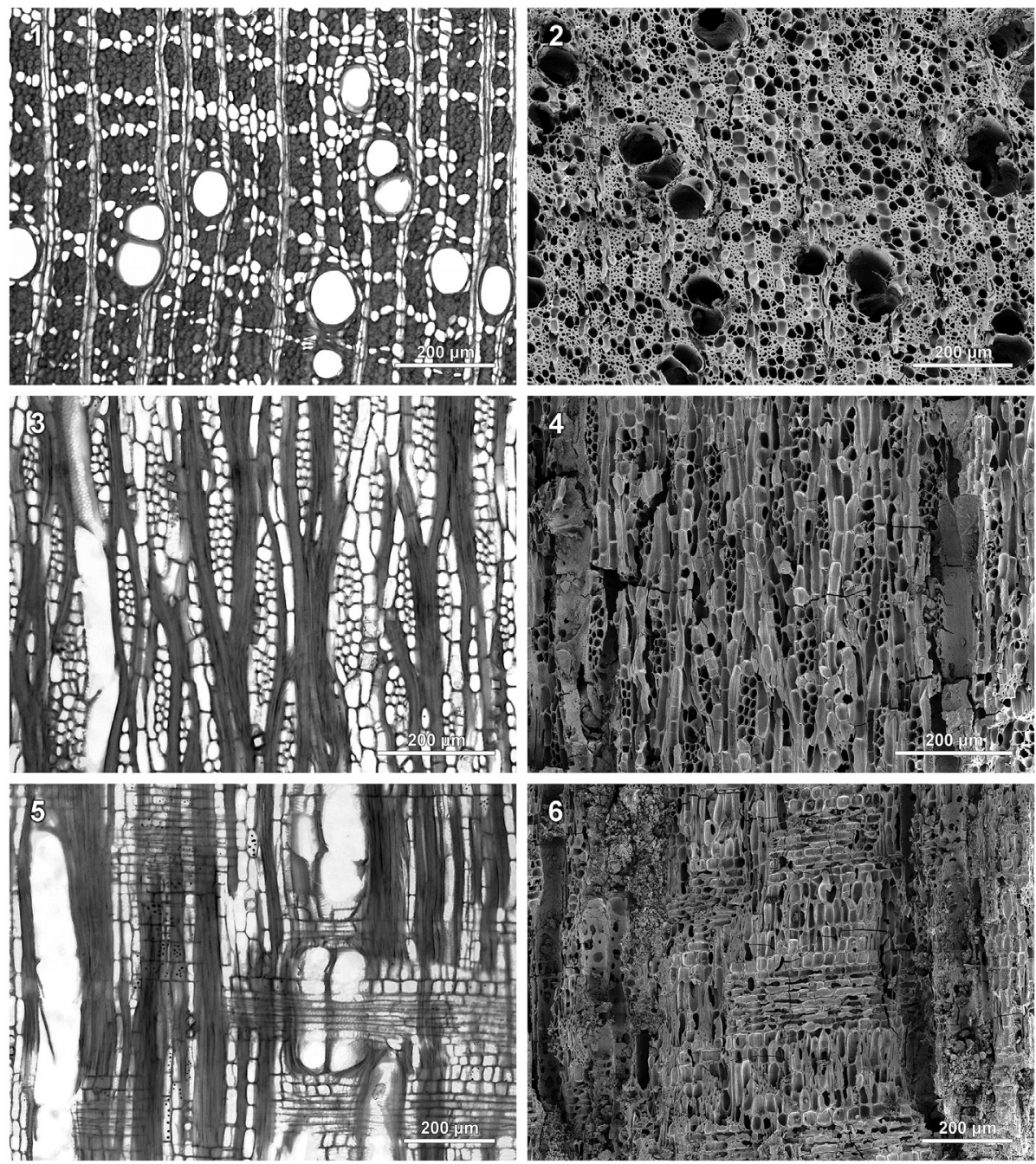

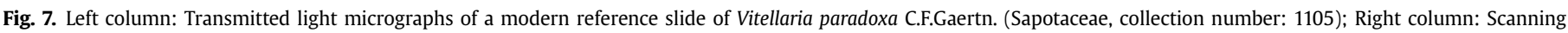
Electron Micrographs of charcoal type Sapotaceae. 1-2: Transversal view; 3-4: Tangential view; 5-6: Radial view.

smelting. These plant families are, indeed, highly and ubiquitously represented in the wood charcoal assemblages of the iron smelting sites. However, the assemblages also contain a number of taxa belonging to other families, which were not explicitly mentioned in the interviews to be useful for iron smelting, though most of them only occurred in small proportions. It is noteworthy that none of the interviewees mentioned the shea butter tree or any other Sapotaceae as valuable fuel for iron smelting or as source for the production of charcoal in Dimuri (see below). This is particularly striking because the Sapotaceae type is well represented in the charcoal record.

At the charcoal production village Dimuri, an old woman could still report on charcoal manufacture and sale. Charcoal production concentrating on only two tree species (Prosopis africana, Burkea africana) was the primary commercial activity of the village. The trees were completely felled and converted into charcoal, which was then sold on the market of Bandjeli, one of the contemporaneous iron smelting centres. However, not all iron smelters were able or needed to buy pre-fabricated charcoal. It seems that they rather followed an opportunistic strategy: When little money was available and they had enough free working capacity, people would use wood from their bush fields and fallows to produce their own charcoal, whereas, in periods when time was scarce and enough money was available they would buy charcoal on the market.
However, there is no means to test if and how long this opportunistic strategy was used and if it was employed in the past. Furthermore, so far there is no archaeological data to elucidate at which point in time specialised charcoal production emerged in the area.

The interviews also revealed that people were well aware of different tree species responding in different ways to felling. While some species are able to re-sprout, even after complete cutting close to the ground, others, particularly Prosopis africana, are considered to hardly regenerate after felling. Therefore, some species, including Prosopis africana, have become rare around villages according to the interviewees.

\section{Discussion}

7.1. What drove the fuel choice of the Bassar iron smelters - fuel quality, cultural factors, or availability?

During the ethnohistorical surveys on fuel choice, the interviewees emphasized the importance of using a few distinct species for charcoal during iron smelting. The anthracological results provided evidence for the predominant use of species with a high wood density, which indicates that species were not randomly exploited, but rather selected according to specific attributes. 

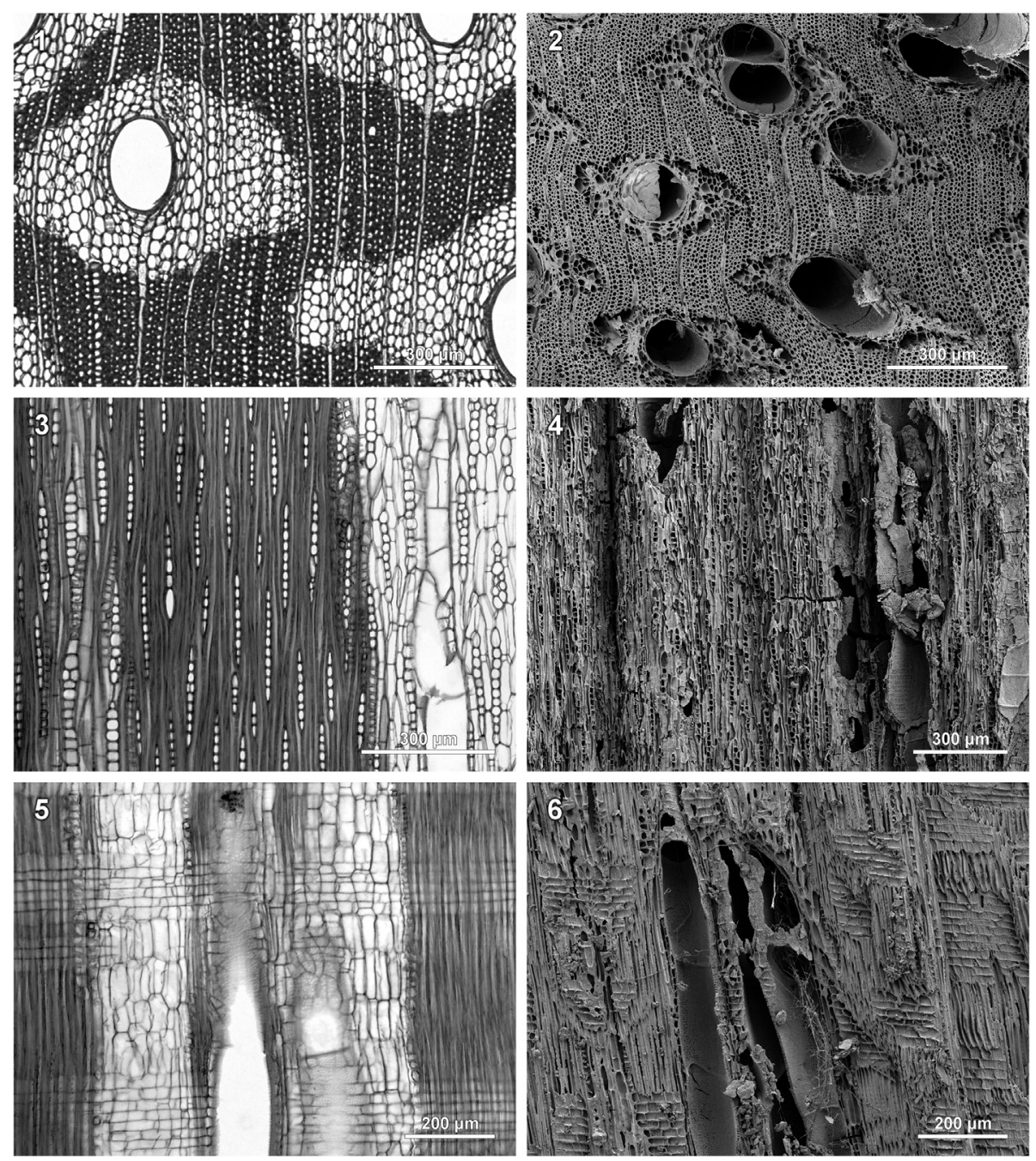

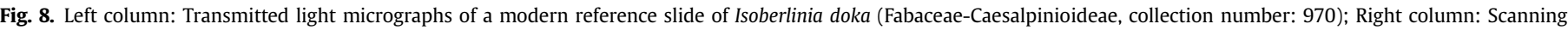
Electron Micrographs of charcoal type Isoberlinia spp. 1-2: Transversal view; 3-4: Tangential view; 5-6: Radial view.

In a standard book on firewood crops, the National Academy of Sciences (1980: 24) stated: "Most woods burn but there are properties that differentiate their value for fuel." Which of these properties are decisive for the fuel quality is, however, still under investigation and a matter of debate. The National Academy (1980) judged wood density as the most important character in determining fuel quality, stating a direct correlation between the dry weight of a wood and its calorific value. Shelton and Shapiro (1976) considered wood with high density and low moisture content preferable as fuel because of its high energy content per volume unit. Klasnja et al. (2013) found higher calorific values for the dense wood of black locust compared to the lower-density woods of willow and poplar species. In contrast, when investigating the calorific values and wood densities of 15 African tropical rainforest taxa in the DR Congo, Hubau et al. (2014) did not find a positive correlation between wood densities and calorific values. Furthermore, within a single species (Musanga cecropiodes) both factors varied distinctly between different plant parts. Munalula and Meincken (2009) provided evidence for the direct correlation of these values for five South African fuel wood species, though the calorific values of the different species varied only in a very narrow range. Wood with high density might even have a relatively low calorific value if the inorganic extractive value is high (Doat, 1975;
Sotelo Montes et al., 2011). A number of other factors may also be decisive for the quality of wood species for fuel, and still further factors may apply if the wood is converted into charcoal before its final use as fuel. Generally, firewood species with slow burning rates may be preferred as fuel (Tietema et al., 1991). High-density wood is reported to have a higher charcoal yield than lowdensity wood (Fuwape, 1993), and Fuwape and Akindele (1997) have found a higher fixed-carbon and ash content for charcoal than for wood and, in their opinion, this possibly accounts for the longer burning period of charcoal. They also stated a significant correlation between the fixed-carbon content and the gross heat of combustion, both higher in the charcoal than in the wood of the same species. According to Corradi Pereira et al. (2012), the use of very dense wood for charcoal production results in higher amounts of charcoal for a certain volume of wood and the charcoal quality is improved for various technical purposes, such as the production of pig iron and steel.

Prehistoric wood fuel use for various purposes in Africa was often neither considered particularly selective nor influenced by specific wood qualities, but rather driven by its accessibility in the surrounding vegetation (e.g. Prior and Price-Williams, 1985; Cartwright and Parkington, 1997; Neumann et al., 1998; Eichhorn, 2004; Höhn and Neumann, 2012; Hubau et al., 2014). Alternatively, 
Table 2

Wood density values $\left(\mathrm{g} / \mathrm{cm}^{3}\right)$ for taxa represented in the charcoal assemblages drawn from the literature $(\mathrm{BD}=$ basic density under bark $=$ dry weight per green volume; $\mathrm{AD}=$ air dry density = dry weight at $12 \%$ moisture content, $\mathrm{NI}$ : no information). Values rounded to the second decimal place. Caesalpinioideae undiff. range based on values for Burkea africana, Tamarindus indica; Terminalia spp. mean based on values for Terminalia avicennioides, Terminalia laxiflora, Terminalia macroptera; Rubiaceae mean based on Crossopteryx febrifuga, Feretia apodanthera, Gardenia ternifolia; Bauhinia spp. mean based on Piliostigma reticulatum, P. thonningii; Lannea spp. mean based on Lannea acida, Lannea microcarpa; Chrysobalanaceae based on Parinari curatellifolia; Acacia spp. mean based on 7 Acacia species in Nygard and Elfving (2000); Syzygium spp. based on S. guineense and S. cordatum, Phyllanthaceae undiff. based on Phyllanthus discoideus. No species information available for Uapaca spp.

\begin{tabular}{|c|c|c|}
\hline Taxon & Wood Density $\left(\mathrm{g} / \mathrm{cm}^{3}\right)$ & References \\
\hline Pericopsis laxiflora & $0.79(\mathrm{NI})$ & Picard et al., 2006 \\
\hline \multirow[t]{3}{*}{ Prosopis africana } & $0.91-1.04(\mathrm{AD})$ & Carsan et al., 2012 \\
\hline & $0.62(\mathrm{BD})-0.7(\mathrm{AD})$ & Sotelo Montes et al., 2011 \\
\hline & $0.69(\mathrm{BD})$ & Nygard and Elfving, 2000 \\
\hline \multirow[t]{2}{*}{ Vitellaria paradoxa } & $0.7(\mathrm{BD})$ & Nygard and Elfving, 2000 \\
\hline & $0.76(\mathrm{NI})$ & Picard et al., 2006 \\
\hline Caesalpiniodeae undifferentiated & $0,73-1.14(\mathrm{AD})$ & \\
\hline Terminalia spp. & $0.64(\mathrm{BD})$ & Nygard and Elfving, 2000 \\
\hline Combretum glutinosum & $0.69(\mathrm{BD})$ & Weber et al., 2017 \\
\hline Detarium microcarpum & $0.57(\mathrm{BD})$ & Nygard and Elfving, 2000 \\
\hline Detarium senegalense & $0.6-0.9(\mathrm{AD})$ & El-Kamali, 2011 \\
\hline Pterocarpus erinaceus & $0.66(\mathrm{BD})$ & Nygard and Elfving, 2000 \\
\hline Rubiaceae & $0.65(\mathrm{BD})$ & Nygard and Elfving, 2000 \\
\hline Bauhinia spp. & $0.65(\mathrm{BD})$ & Nygard and Elfving, 2000 \\
\hline Entada africana & $0.52(\mathrm{BD})$ & Nygard and Elfving, 2000 \\
\hline Lannea spp. & $0.47(\mathrm{BD})$ & Nygard and Elfving, 2000 \\
\hline Lophira lanceolata & $0.81-0.9(\mathrm{AD})$ & Carsan et al., 2012 \\
\hline Chrysobalanaceae & $0.62(\mathrm{BD})$ & Picard et al., 2006 \\
\hline Isoberlinia doka & $0.65(\mathrm{NI})$ & Picard et al., 2006 \\
\hline Strychnos spinosa & 0.69 (BD) & Nygard and Elfving, 2000 \\
\hline Anogeissus leiocarpa & $0.72(\mathrm{BD})$ & Nygard and Elfving, 2000 \\
\hline Acacia spp. & $0.74(\mathrm{BD})$ & Nygard and Elfving, 2000 \\
\hline Uapaca spp. & $0.6(\mathrm{NI})$ & Reyes et al., 1992 \\
\hline Phyllantaceae undifferentiated & $0.76(\mathrm{AD})$ & Reyes et al., 1992 \\
\hline Syzygium spp. & $0.65-0.80(\mathrm{AD})$ & Carsan et al., 2012 \\
\hline
\end{tabular}

Table 3

Woody taxa used as fuel for iron smelting in the northwestern Bassar region according to the ethnohistorical interviews.

\begin{tabular}{|c|c|c|c|}
\hline & Belemele & Bissibe & Tabale \\
\hline Charcoal for smelting & $\begin{array}{l}\text { Prosopis africana } \\
\text { Pericopsis laxiflora } \\
\text { Burkea africana }\end{array}$ & $\begin{array}{l}\text { 'strong' } \\
\text { Prosopis africana } \\
\text { Burkea africana } \\
\text { Pericopsis laxiflora } \\
\text { 'less strong' } \\
\text { Combretum spp. } \\
\text { Detarium microcarpum }\end{array}$ & $\begin{array}{l}\text { ‘strong' } \\
\text { Burkea africana } \\
\text { Prosopis africana } \\
\text { Pericopsis laxiflora } \\
\text { Afzelia africana } \\
\text { 'less strong' } \\
\text { Terminalia spp. } \\
\text { Combretum spp. }\end{array}$ \\
\hline $\begin{array}{l}\text { Added fresh wood } \\
\text { For smelting }\end{array}$ & Pericopsis laxiflora & Afzelia africana & $\begin{array}{l}\text { Detarium microcarpum } \\
\text { Pterocarpus erinaceus } \\
\text { Entada africana } \\
\text { Daniellia oliveri }\end{array}$ \\
\hline
\end{tabular}

specialized technical applications, specifically techniques requiring high temperatures, may well have led to a conscious and selective choice of species in order to obtain high quality fuel. This is highly significant at the Egyptian site of Amarna, where Acacia nilotica charcoal dominated the assemblages at the vitreous material fabrication sites by $90 \%$. In associated slags, Acacia nilotica charcoal was exclusively present. In contrast, fuelwood species composition in household contexts was distinctly more diverse (Zakrzewski et al., 2016: 311-312).

In the Bassar iron smelting chaîne opératoire, the conversion of wood into charcoal before its final use for iron smelting is an important step that is intercalated between wood collection and fuel use and might trigger selectivity. Fuel collection for charcoal production may already be highly selective as evidenced by current rural charcoal production in Togo. Countrywide, only 34 out of 158 woody species identified on plots in four charcoal production areas are exploited for the manufacture of wood charcoal. In the Bassar area's charcoal production zone, only four first choice tree species are used in high proportions, whereas, three other species are used in minor proportions only. In this context, the level of use of a woody species does neither correspond to its frequency, density, nor to its dominance in the vegetation (Kouami et al., 2009: Table 2).

In a comprehensive overview of iron-smelting throughout subSaharan Africa, Celis (1991: 23) summarized which criteria ironworkers used when selecting wood species for charcoal production. Iron smelting charcoal was mainly produced from species with particularly heavy and hard wood because, at least in in the opinion of the smelters, these species produce more heat than others. They were convinced that these woods were indispensable for the iron smelting process and that the reduction of iron ore would otherwise not be successful. Celis (1991) pointed out that in recent periods it became difficult for the smelters to find the species prescribed by their traditions, but they barely scrutinised the value of these traditions. In fact, replacing the traditional hard wood species by exotic ones such as Eucalyptus species did not impede a 
successful smelt. However, the cultural tradition of the iron smelters was in conflict with the use of other wood species.

Comparing the charcoal analysis results from the two major Bassar area iron smelting sites, Tchogma and Tatré, with oral traditions on wood use for iron smelting has revealed general conformity, as well as discrepancies in the archaeobotanical and ethnohistorical data, which are worth considering in detail. Woody taxa, which are remembered to have been intentionally selected as sources of fuel for iron smelting due to their presumed higher fuel quality, are prominently, but not exclusively, represented in the charcoal assemblages of the iron smelting sites. In particular, the Sapotaceae are regularly represented and sometimes constitute a significant proportion of charcoal fragments. In the case of the Bassar sites, this charcoal type most probably represents the shea butter tree (Vitellaria paradoxa), one of the dominant agroforestry species of the region (see Results and wood anatomical descriptions in the Appendix). The shea butter tree is an extremely useful fruit tree for yielding oil-rich fruits and, therefore, together with other useful trees, spared from felling when preparing fields, thus, an important agroforestry parkland constituent (Boffa, 1999; Kahlheber, 1999; Teklehaimanot, 2004; Höhn and Neumann, 2012; Eichhorn and Neumann, 2013). The relative proportions of Vitellaria paradoxa trees in the vicinity of settlements, particularly in cultivated fields and fallows, are, thus, higher in comparison to vegetation that has been little affected by human use and they are easily available as a source of fuel. Though vigorously growing trees are spared because of their fruits, dead and/or little productive individuals (e.g. old trees, trees with small fruits) are felled and subsequently used as fuel. In fact, the wood of the shea butter tree yields high quality fuel and is one of the most important firewoods in southeastern Burkina Faso (Gallagher, 2010: Table 3.5). Its frequent use in iron metallurgy in Burkina Faso is indicated by ethnobotanical interviews (Kiéthéga, 2009, 249 ff.). The use of shea butter tree wood for iron smelting at the Bassar sites is consistent with our observations at the Fiko Tradition sites in Mali where this species has been regularly used for the same purpose as evidenced by charcoal analysis (Eichhorn, 2012; Eichhorn et al., 2013 a,b; Eichhorn and Neumann, 2013). Neither in Mali nor in Togo was Vitellaria paradoxa mentioned as a useful tree for iron smelting during our ethnohistorical interviews. Its regular appearance in the charcoal assemblages of the iron smelting sites may simply reflect its general availability in the surrounding vegetation, but might also indicate that other preferred taxa were not available in sufficient amounts - either due to their overuse for smelting or to increasing conversion of savanna and woodland vegetation to arable land.

In summary, our results concerning Bassar fuelwood choice for iron smelting based on charcoal analysis and ethnohistorical data indicate that both, cultural factors and availability, were of major importance, whereas we could so far not securely correlate the choice of species believed by the iron-smelters to be of superior quality with objective fuel quality criteria. The cultural factors and the belief in the exquisite fuel quality of certain species may have stipulated the prevalent selection of woody taxa prescribed by the iron smelting traditions. The 'principle of least effort' of human behavior, postulating that every individual will naturally choose the path of least resistance (e.g. Ferrero, 1894; Zipf, 1949) is commonly referred to in anthracology to explain human procurement of fuel. It may serve as an argument that the surrounding vegetation is well-reflected in charcoal assemblages when woody species were randomly collected according to their availability in the surrounding vegetation (e.g., Shackleton and Prins, 1992; Marston, 2009; Théry-Parisot et al., 2010; Hubau, 2014). Théry-Parisot et al. (2010) have proposed a review of the taphonomical processes which affect archaeological assemblages. Human habits are the first of a number of successive filters which determine if and how the past vegetation is reflected in anthracological reconstruction. At Bassar the 'principle of least effort' was distinctly and visibly superimposed by this "societal filter".

\subsection{The ecological impact of Bassar iron smelting - an unresolved question?}

Based on published data on Bassar slag volumes and iron production (DeBarros, 1986), our working hypothesis was that the overuse of woody biomass, which was previously linked to vegetation degradation due to Bassar iron metallurgy, would be unlikely. In contrast, our recent archaeometallurgical studies have provided evidence that iron production and, thus, wood consumption in the Bassar area was more intensive than previously thought. This evidence is based on the following: 1. Refined topographical measurements of the metallurgical waste heaps with tacheometry; 2 . Intensive prospections leading to the discovery of hitherto unknown metallurgical sites in the Bassar area, among them huge sites made up of hundreds of slag heaps; 3. Systematic slag mass per volume measurements (Robion-Brunner and Serneels, 2017). At Tatré 4, our new topographical measurements of the metallurgical waste heaps resulted in a volume of $6,000 \mathrm{~m}^{3}$, whereas De Barros (1986: Fig. 4) had assigned this site to the volume category $2000-5000 \mathrm{~m}^{3}$. With the help of six 'cubages' we could calculate the slag mass per volume at Tatré. Considering the type of metallurgical waste assemblage (Table 4), around 8'000 tonnes of slag have been produced at Tatré 4 .

Yet, even if we assume that the total slag amount in the Bassar area was previously significantly underestimated, wood biomass reproduction in the whole Bassar area would still have been sufficient to fulfil the fuel requirements of iron smelting. This is due to the high amount of annual precipitation in the southern Sudanian zone allowing for high rates of wood mass regeneration and the vast land surface of the Bassar area (Eichhorn et al., 2013 a,b: Fig. 8).

Such a simplified attempt to quantify wood consumption and woodland regeneration for a large area only allows for a crude estimate of the intensity of fuel use and wood fuel availability and can neither consider local variation within the area due to site distribution or ecological differences resulting in variations of biomass reproduction, nor can it consider temporal differences due to periods with varying production levels. Furthermore, it cannot take the preferential use of certain species into account. Locally, in vicinity of metallurgical production centres such as Tatré or Tchogma, over-exploitation of woody vegetation may well have occurred. This seems, in fact, to be indicated by distinctive erosion phenomena in the Tatré River valley, probably linked to vegetation opening which are contemporaneous with intensive iron smelting at Tatré (Aline Garnier, personal communication, 2016). They consist of upstream colluvial-alluvial depositions and downstream incisions into earlier deposits. Hahn (1997) proposed a hypothetical model of deforested areas expanding in gradually widening circles around metallurgical sites. This model could be applied to the major Bassar sites operating intensively and on a long-term basis, although rapid woodland regeneration must be considered for these areas as well.

Table 4

Mass of slag per $\mathrm{m}^{3}$ depending on the type of metallurgical waste assemblage.

\begin{tabular}{ll}
\hline The metallurgical waste assemblage & Quantity of slag per $\mathrm{m}^{3}$ \\
\hline $80 \%$ of tapped slags & $1800 \mathrm{~kg}$ of slag \\
$60 \%$ of tapped slags & $1300 \mathrm{~kg}$ of slag \\
$40 \%$ of tapped slags & $850 \mathrm{~kg}$ of slag \\
$20 \%$ of tapped slags & $500 \mathrm{~kg}$ of slag \\
\hline
\end{tabular}


What could be even more likely than woodland overexploitation are changes in woodland composition due to the selective exploitation of particular species. Species capable of resprouting quickly after cutting most likely gained importance around the metallurgical sites. In fact, these species are represented in the charcoal assemblages from the beginning in the sequences of Tatré and Tchogma (e.g. Pericopsis laxiflora; Combretum spp. and Terminalia spp). It is likely that they were not only favoured by wood cutting for intensive iron smelting, but probably also by the earlier establishment of agroforestry systems with fields and fallows and for wood gathering for domestic purposes. The general availability of iron agricultural tools facilitated the expansion of cultivated areas as well as the cultivation of labour-intensive crops such as yams. All in all, it seems likely that the direct consequences of intensive iron smelting on the vegetation and more indirect impacts caused by clearance for intensive cultivation are difficult to disentangle.

Local differentiation that developed during Bassar's iron metallurgy history, such as the emergence of specialised charcoal producing sites and the spatial separation of different wood fuel consuming activities (smelting, refining, smithing; see De Barros, 1986), are likely to have moderated the net impact of wood exploitation for metallurgy. The mountainous areas, which were unfavourable for cultivation, were most probably an important source of wood for charcoal producers. Today the mountainous slopes around the town of Bassar, as well as hill slopes close to villages, are still strongly impacted by human activity, specifically wood cutting for domestic fires and other purposes. Here, woody vegetation is locally dominated by vigorously re-sprouting stumps of taxa such as Pericopsis laxiflora or Isoberlinia spp. (own observations, January 2014). It is highly likely that vegetation composition on slopes and close to the smelting sites was already earlier altered by wood use for iron smelting though this is not unequivocally reflected in the charcoal data.

\section{Conclusion}

This study aimed at interpreting wood use for iron smelting in the Bassar area as well as reconstructing possible human impacts of wood exploitation through time. Anthracological analyses have shown a high degree of similarity in the composition of charcoal assemblages derived from different sites pointing to the selective use of hard wood taxa available in the area. There is general agreement with the ethnohistorical interviews on wood use for iron metallurgy in the area which emphasise the use of a few hard wood taxa for charcoal used as iron smelting fuel. However, the charcoal assemblages point to the regular additional use of certain taxa not mentioned by the interviewees, particularly of agroforestry parkland species that are widely available in the area. The establishment of a detailed chronology and of site-specific chronologies allowing for the establishment of long-term charcoal sequences was hampered by unreliable radiocarbon dating and a number of radiocarbon dates attributed to phases with radiocarbon curve plateaus. This problem could partly be addressed for the latest phases by drawing information from oral traditions. Reinvestigation of Bassar iron production indicates that the average annual slag output was higher than previously thought. Simplistic assumptions of a general deforestation of the area nevertheless do not apply to Bassar. In contrast, local over-exploitation favouring localised soil erosion and particularly changes in vegetation composition due to the expansion of certain species capable of fast regeneration after cutting are probable. These phenomena went hand in hand with agricultural intensification leading to similar outcomes.

\section{Acknowledgements}

We are very much indebted in the Agence Nationale de Recherche (France) for funding research within the ANRJC project SIDERENT ('Sidérurgie et Environnement au Togo: Stratégie d'exploitation des ressources naturelles dans le cadre d'une production du fer ancienne et intensive (région bassar, Togo)'), ANR13-JSH3-0002-01.

We thank all colleagues collaborating in the SIDERENT project, in particular Aline Garnier who provided details on erosion phenomena in the Tatré River valley.

Particular thanks are due to Philip de Barros for sharing his vast knowledge of the region and for friendly supporting the establishment of current research in the Bassar area.

We are grateful to all Bassar interviewees and informants for their hospitality and for sharing their memories of iron smelting traditions.

We wish to thank Smiti Nathan for language editing, Manfred Ruppel and Niklas Döring for taking the SEM photos of wood charcoal and Gabriele Försterling for image editing.

We also thank Alexa Höhn and Katharina Neumann for many years of fruitful discussions on vegetation change in West Africa.

Last, but not least we are very grateful to the two anonymous reviewers for their extremely valuable comments to and improvements of the initial manuscript.

\section{Appendix}

Short wood anatomical descriptions of the identified wood charcoal types

In the following descriptions, only clearly visible characters are listed. Pit size is in the text descriptions only mentioned when minute or large. Unless otherwise stated, we only observed nonseptate fibres with simple to minutely bordered pits. Growth ring boundaries are only mentioned when distinct and visible in the charred archaeological material. Septate fibres are only mentioned when securely observed. The provided IAWA codes (IAWA Committee, 1989) refer to the characters observed in the charcoal types, not to characters in reference material. Character 179 (Tropical Africa) should be used with caution. For the youngest phases at Bassar, the presence as well as the use of introduced taxa for fuel cannot definitely be excluded. Brackets indicate that the character was only rarely observed whereas question marks indicate that the character was possibly present, but not unequivocally discernible.

\section{Prosopis africana type (Fig. 5)}

Growth ring boundaries mostly indistinct, rarely distinct. Vessels solitary, in small clusters or short rows. Simple perforation plates. Intervessel pits vestured. Vessel-ray pits bordered, similar to intervessel pits. Paratracheal axial parenchyma mainly vasicentric, occasionally aliform, rarely conflent. Apotracheal parenchyma diffuse (rare). Banded axial parenchyma: in marginal or seemingly marginal bands (rare). 2-4 cells per parenchyma strand. Ray width 1 to 3 cells. All ray cells procumbent. Prismatic crystals in chambered axial parenchyma cells.

IAWA code: (1), 2, 5, 13, 22, 26, 29, 30, 61, 66, 69, 70, 79, 80, (81), (83), 91, 92, 97, 104, 136, 142, 179.

Remark:

In modern reference material of Prosopis africana, the distinction from some members of the Fabaceae-Caesalpinioideae is not always secure, particularly in individuals with abundant axial parenchyma. Therfore, we only counted fragments with distinct and predominant vasicentric axial parenchyma as Prosopis africana 
type, a character which we did not observe in other Fabaceae with the exception of Acacia nilotica. The latter differs, however, by the presence of wider and higher rays.

A similar type was described and displayed in Höhn (2005) as cf. Prosopis africana and references were given to earlier finds and descriptions which will not be repeated here. Images of this type from metallurgical sites in Mali were displayed in Eichhorn (2012) and Eichhorn et al. (2013b) as Prosopis africana.

\section{Acacia type}

Growth ring boundaries generally distinct. Vessels mainly solitary, in small clusters and short radial rows. Intervessel pits vestured. Vessel-ray pits with distinct borders, similar to intervessel pits. Paratracheal axial parenchyma aliform, confluent, rarely banded. Appotracheal axial parenchyma diffuse (rare, as single crystalliferous cells). Marginal or seemingly marginal parenchyma present. Axial parenchyma fusiform (rarely), and two to four cells per parenchyma strand. Rays 1-6 seriate in the material investigated here. All ray cells procumbent. Prismatic crystals in chambered axial parenchyma cells.

Remark: A similar type was described and displayed in Eichhorn (2004) as Acacia spp. for southwestern Africa. Höhn (2005) displayed and described a similar type as Acacia sp. and provided references to earlier finds.

IAWA code: 1, (2), 5, 13, 22, 25, 26, 29, 30, 61, 66, 69, 70, (76), 79, 80, 81, 83, (85) 89, (90), 91, 92, 98, 104, 136, 142, (156), 179.

\section{Entada spp.}

This type is very similar to the previous Acacia type, but differs distinctly, mainly by the presence of distinct, regular broad parenchyma bands. Vasicentric, aliform and lozenge aliform axial parenchyma not observed. Two species with similar wood anatomy are included in this type, Entada africana and E. abyssinica.

IAWA code: 2, 5, 13, 22, 26, 29, 30, 61, 66, 69, 70, 83, 85, (90), 91, 92, 98, 104, 136, 142, 179.

\section{Caesalpinioideae, undifferentiated}

Vessels solitary, in small clusters or short rows. Simple perforation plates. Intervessel pits vestured. Vessel-ray pits bordered, similar to intervessel pits. Paratracheal axial parenchyma: mainly vasicentric, aliform, lozenge-aliform, confluent. Banded parenchyma: In marginal or seemingly marginal bands (variable). 24 cells per parenchyma strand. Ray width 1 to 3, rarely up to 4 cells. All ray cells procumbent. Prismatic crystals in chambered axial parenchyma cells.

IAWA code: (1), 2, 5, 13, 22, (25), 26, (27), 29, 30, (58), 61, 66, 69, (70), 79, 80, 81, 83, (89), 91, 92, 97, 104, 136, 142, 179.

Remark.

This type comprises a high amount of taxa of the Fabaceae subfamily Caesalpinioideae. One of the species preferably used for Bassar iron smelting according to oral traditions, Burkea africana, is merged in this type. Burkea africana cannot be securely differentiated from other taxa in the Caesalpinioideae. Charcoal originating from Prosopis africana wood with abundant parenchyma would also be comprised in this charcoal type.

\section{Bauhinia spp.}

Vessels predominantly in short radial rows. Intervessel pits not vestured. Vessel-ray pits with reduced borders to apparently simple. Paratracheal axial parenchyma confluent. Banded axial parenchyma: more than three cells wide. 2-4 cells per parenchyma strand. Rays exclusively uniseriate. Rays heterocellular. Body ray cells procumbent with one to two rows of upright and/or square marginal cells. Rays and vessel elements storied (sometimes irregularly). Prismatic crystals present, in chambered axial parenchyma cells.

IAWA code: (1), 2, 5, 13, 22, 26, 31, 61, 66, 69, 70, 83, 85, (89), 91, 92, 96, 106, (107), 118, 120, (122), 136, 142, 179.

Remark.

A similar charcoal type was described and displayed as Bauhinia/ Piliostigma by Höhn (2005) and she provided references to earlier finds. In contrast to our own observations based on the Frankfurt wood slide reference collection and to Höhn (1999), the vessel-ray pits of Bauhinia reticulata and $B$. thonningii are described in the InsideWood database (InsideWood, 2004 onwards) as: 'with distinct borders; similar to intervessel pits in size and shape throughout the ray cell'. The character combination of 'Rays and vessel elements storied', 'Rays exclusively uniseriate' and 'Vesselray pits with reduced borders to apparently simple' are very distinctive and allow for a safe distinction from other Fabaceae in the area.

\section{Isoberlinia spp. (Fig. 8)}

Vessels mainly solitary and in small clusters. Intervessel pits vestured. Vessel-ray pits with distinct borders, similar to intervessel pits. Paratracheal axial parenchyma predominantly distinctly aliform, lozenge-aliform or winged-aliform, rarely confluent. Banded axial parenchyma: In marginal or in seemingly marginal bands. Two to four cells per parenchyma strand. Rays exclusively uniseriate (rarely 2-seriate). Body ray cells procumbent with one row or with $2-3$ rows of upright/square marginal cells. Rays sometimes with procumbent and square (not with upright!) cells throughout the ray (rare). Prismatic crystals in chambered axial parenchyma cells.

Remark.

This type differs from the type 'Caesalpinioideae, undifferentiated' by the combination of predominantly distinctly aliform parenchyma and exclusively uniseriate rays with one to several rows of marginal cells. This character allows for the distinction from other Fabaceae-Caesalpinioideae occurring in the research area, e.g. Tamarindus indica, Burkea africana and Afzelia africana. In these species all ray cells are procumbent. The genera Didelotia, Bikinia, Tetraberlinia, Gilbertiodendron have a very similar character combination, but their geographical distribution does not extend to Central Togo (African Plant Database, retrieved July 2017). In the Frankfurt reference collection of West African FabaceaeCaesalpinioideae, rays with more than one row of marginal square cells are restricted to the genus Isoberlinia.

IAWA code: $1,(2), 5,13,22,25,29,30,(58), 61,66,69,80,81,82$, 89, 91, 92, 96, 106, 107, (109), 136, 142, 179.

\section{Pericopsis spp. (Fig. 6)}

Growth ring boundaries generally distinct (marked by marginal parenchyma bands), vessels solitary, in small clusters or in short rows. Simple perforation plates. Intervessel pits vestured. Vesselray pits bordered, similar to intervessel pits. Apotracheal axial parenchyma diffuse (rare). Paratracheal axial parenchyma aliform, lozenge-aliform, confluent, rarely unilateral. Banded parenchyma in marginal or seemingly marginal bands. 2-4 cells per parenchyma strand. Ray width mainly 1 to 3 cells, rarely up to 4 cells. All ray cells procumbent. All rays, axial parenchyma and/or vessel elements storied. Prismatic crystals in chambered axial parenchyma cells.

Remark.

Although the charcoal fragments of this type are often strongly vitrified, the distinct storied structure and the characteristic axial parenchyma distribution remain discernible. In contrast to otherwise similar Fabaceae-Papilionoideae, Pericopsis spp. has always a high amount of aliform to lozenge-aliform parenchyma. In transversal view, confusion with charcoal of Terminalia spp. is sometimes possible, in the latter the storied sructures are, however, absent. 
IAWA code: $1,(2), 5,13,22,26,29,30,61,66,70,(76), 80,81,82$, 83, 91, 92, 97, 104, 118, 120, 136, 142, 179.

\section{Detarium spp.}

Vessels solitary or in short rows, rarely in small clusters. Simple perforation plates. Intervessel pits vestured. Vessel-ray pits bordered, similar to intervessel pits. Paratracheal axial parenchyma vasicentric, aliform, lozenge-aliform, rarely confluent. Banded parenchyma in marginal or seemingly marginal bands. 2-4 cells per parenchyma strand. Ray width 1 to 3 cells, larger rays commonly up to 5 , rarely up to 8 cells. All ray cells procumbent, or ray cells procumbent with one row of upright and/or square marginal cells. Prismatic crystals in chambered axial parenchyma cells. Axial intercellular canals in distinct tangential bands. The two species of this genus in the area, D. microcarpum and $D$. senegalense cannot be distinguished on the basis of their anatomy. We consider the distinct bands with intercellular canals as a good character to distinguish Detarium spp. from other Caesalpinioideae in the area.

IAWA code: $1,2,5,13,22,26,27,29,30,61,66,(68), 69$, (76), 79, 80, 81, (82), (83), 89, 91, 92, 97, 98, 104, 106, 127, 136, 142, 179.

Remark.

A similar type has been described and displayed in Höhn (2005) as Detarium microcarpum and she provided references to earlier finds.

\section{Pterocarpus type erinaceus}

Vessels solitary, in small clusters or short rows. Simple perforation plates. Intervessel pits vestured. Vessel-ray pits bordered, similar to intervessel pits. Paratracheal axial parenchyma predominantly in narrow lines up to three cells wide, rarely aliform to confluent. Apotracheal parenchyma predominantly diffuse-inaggregates. 2 cells per parenchyma strand. Rays exclusively uniseriate or rarely with a biseriate portion in the central part. All ray cells procumbent. All ray, axial parenchyma and/or vessel elements storied. Prismatic crystals in chambered axial parenchyma cells.

Remark.

Pterocarpus lucens, occurring further north in the SaheloSudanian phytogeographic zones, differs mainly by less regularly arranged axial parenchyma ( $P$. lucens has a high amount of diffuse and diffuse-in-aggregates parenchyma). This species can be excluded in our context because of its natural distribution. In Pterocarpus santalinoides, a riverine species, diffuse and diffuse-inaggregate parenchyma seems absent. This differentiation is, however, marginal and confusions cannot be securely excluded. Höhn (2005) describes and displays the type Pterocarpus lucens and gives references to earlier finds.

IAWA code: $2,5,13,22,25,26,29,30,(45),(58), 61,66,69$, (70), (76), (77), (80), (82), (83), 86, 91, 96, (97), 104, 118, 120, 121?, 136, $142,179$.

\section{Sapotaceae (Fig. 7)}

Vessels mainly in short radial rows, radial multiples of 4 or more uncommon in the analysed charcoal fragments and in part of the modern reference material of Vitellaria paradoxa. Thin-walled tyloses common in some charcoal fragments. Simple perforation plates. Intervessel pits minute to small. Vessel-ray pits with distinct borders; similar to intervessel pits in size and shape throughout the ray cell and vessel ray pits with much reduced borders to apparently simple, often scalariform. Vessel-ray pits of two distinct sizes in the same ray cell. Vascular/vasicentric tracheids present. Axial parenchyma diffuse, diffuse-in-aggregates, rarely in bands up to three lines wide. 4-8 cells per parenchyma strand. Ray width 13 cells. Rays with multiseriate portion(s) as wide as uniseriate portions common (variable). Body ray cells procumbent, rarely with one, more often with up to 4 rows of upright and/or square marginal cells. Prismatic crystals in axial parenchyma cells and crystal sand observed in some fragments, variable. Silica not observed.

IAWA code: 2, 5, 13, 22, 24, 25, 30, 31, 32, 33, (56), 60, 61, 66, 70, 76, 77, (86), 92, 93, 97, (100), (106), 107, 108, (136), (141), (142), (153), 179.

Remark.

The taxa of the Sapotaceae family in the area display a high degree of anatomical similarity (cf. Ekblom et al., 2014 for southern Africa). A few taxa are characterized by large decorated silica bodies. The shea butter (Vitellaria paradoxa) slides in our reference collection show either no silica inclusions or rare small particles. Long radial vessel rows are uncommon in Vitellaria paradoxa and the axial parenchyma is irregularly distributed (only rarely in distinct lines several cells wide). We therefore consider the analysed material to represent shea butter tree with a high probability. Höhn (2005) classified and described a similar charcoal type as Vitellaria paradoxa and she provided references to earlier finds.

\section{Terminalia spp.}

Vessels solitary, in small clusters or short rows. Simple perforation plates. Intervessel pits vestured. Vessel-ray pits bordered, similar to intervessel pits. Paratracheal axial parenchyma aliform, lozenge-aliform and confluent. Apotracheal axial parenchyma diffuse. Banded parenchyma: in marginal or seemingly marginal bands (variable). 2-8 cells per parenchyma strand. Ray width 1 to 3 , rarely up to 5 cells. All ray cells procumbent or rarely procumbent with one row of marginal cells. Mineral inclusions not observed.

IAWA code: 1, (2), 5, 13, 22, 26, 29, 30, 61, 66, 69, 70, 76, 79, 80, 81, (82), 83, (89), 91, 92 93, 97, (98), 104, (106), 179.

Remark.

Mainly differs from the otherwise similar type Caesalpinioideae, undifferentiated, by the presence of abundant apotracheal parenchyma. A similar type was described and displayed by Höhn (2005) as Terminalia avicennioides/macroptera and she provided references to earlier finds. In the southern Sudanian phytogeographic zone a number of other Terminalia species have to be considered which cannot be differentiated on the basis of their wood anatomy. A similar type was displayed in Eichhorn et al. (2013b).

\section{Combretum type glutinosum}

Vessels exclusively solitary. Simple perforation plates. Intervessel pits vestured. Vessel-ray pits bordered, similar to intervessel pits. Paratracheal axial parenchyma: aliform and confluent. Axial parenchyma in marginal or seemingly marginal bands (variable). Two to four cells per parenchyma strand. Rays exclusively uniseriate. All ray cells procumbent or rays with procumbent, square and upright cells mixed throughout the ray. Included phloem present, diffuse. Mineral inclusions not observed.

IAWA code: (1), 2, 5, 9, 13, 22, 25, 29, 30, 61, 66, 69, 70, 80, (81), 83, 89, 91, 92, 96, 104, 109, (112), 134, 179.

Remark.

A similar type was described and displayed by Höhn (2005) as Combretum glutinosum and she provided references to earlier finds. Eichhorn et al. (2013b) displayed SEM images as Combretum glutinosum.

\section{Rubiaceae}

Vessels exclusively solitary, or predominantly solitary and rarely in groups of 2-3. Axial parenchyma in most fragments not discernible, sometimes apotracheal-diffuse parenchyma visible. Intervessel pits minute to small. Vessel-ray pits similar to intervessel pits. Fibre pits bordered, common in both radial and tangential walls. Rays width 1-3 cells. Rays with multiseriate portion(s) as wide as uniseriate portions. Body ray cells procumbent 
with 2 to more than 4 rows of upright and/or square marginal cells. Mineral inclusions not observed.

IAWA code: (1), 2, 5, (9), 13, 22, 24, (25), 29 (only discernible in the SEM), 30, 62, 63, 66, 69, 75, 76, 92, 93, 97, 100, 107, 108, (113), 179.

Remark.

The fragments can be attributed to the Rubiaceae wood anatomical subtype I (Jansen et al., 2002). Due to the high number of Rubiaceae in the area with a high degree of anatomical similarity we decided not to distinguish further subtypes. For the Sahel of Burkina Faso, Höhn (2005) distinguished two subtypes based on vessel size, displayed SEM images and provided references to earlier finds.

\section{Phyllanthaceae, undifferentiated}

Vessels mainly in short radial rows. Perforation plates simple. Vessel-ray pits with much reduced borders to apparently simple, pits rounded or angular; or pits scalariform to vertical. Fibres septate, with simple to minutely bordered pits. Axial parenchyma not observed or extremely rare, scanty paratracheal. Four to over eight cells per parenchyma strand. Rays 1-3 cells wide; larger rays commonly four- to ten-seriate (mostly up to five cells). Ray height $>1 \mathrm{~mm}$. Rays heterocellular, body ray cells procumbent with mostly two to over four cells rows of upright and/or square marginal cells; or procumbent, square and upright cells mixed throughout the ray. Prismatic crystals sometimes present in upright and/or square ray cells, in most fragments not observed.

IAWA code: (1), 2, 5, 13, 22, 24, 25, 31, 32, 61, 65, 69, 75, (78), 97, 98, 102, 107, 109, 179 .

Remark: The Phyllanthaceae, undifferentiated charcoal type comprises a number of taxa of the Phyllanthaceae family (e.g. Flueggea virosa, Phyllanthus spp., Hymenocardia spp. which cannot be securely differentiated on the basis of their wood anatomical characters. Charcoal attributed to the type Uapaca spp. are dealt with separately below, as well as fragments tentatively attributed to the genus Antidesma. Described as 'Phyllanthus' type in Ekblom et al. (2013, also see the diagnostic remarks in the OSM). A similar type has been described by Höhn (2005) as Flueggea virosa/Hymenocardia acida and she provided references to earlier finds.

\section{Phyllanthaceae, $c f$. Antidesma}

Similar to the previous type, differs only by the presence of silica bodies in ray cells. Crystals not observed.

IAWA code: 2, 5, 13, 22, 25, 31, 32, 61, 65, 66?, 69, 75, (78), 97, 98, 102, 105, 109, 159, 160, 179.

\section{Uapaca spp.}

Vessels predominantly solitary, rarely in short rows. Scalariform perforation plates not observed. Tyloses common. Intervessel pits large. Vessel-ray pits with reduced borders to apparently simple, pits rounded or angular or horizontal, often scalariform, gash-like to vertical. Fibres non-septate. Apotracheal axial parenchyma diffuse. Paratracheal parenchyma scanty, aliform and confluent. 4 to 8 cells per parenchyma strand. Larger rays commonly 4-10 seriate, very high. Silica bodies present, in ray cells. Body ray cells procumbent with 2 to more than 8 rows of upright and/or square marginal cells.

IAWA code: 2 , 5, (9), 13, 22, 27, 31, 32, 56, 61, 66, 69, 76, 78, 80, (81), 83, 92, 93, 98, 102, 107, 108, 159, 160, 178, 179.

\section{Lophira spp.}

Vessels solitary or in short rows. Intervessel pits minute, vestured. Vessel-ray pits with distinct borders; similar to intervessel pits in size and shape throughout the ray cell. Axial parenchyma in bands more than three cells wide. Over 8 cells per parenchyma strand. Ray width 1-3 cells. All ray cells procumbent. Prismatic crystals in chambered axial parenchyma cells.

Remark.

Lophira lanceolata is the only matching species which is present in the research area. Images of a similar type were provided in Eichhorn and Neumann (2013) as Lophira lanceolata.

IAWA code: 2, 5, 13, 22, 24, 29 (only visible in the SEM), 30, (58), 61, 62?, 66, 70, 85, 94, 97,104, 136, 142, 179.

\section{Chrysobalanaceae}

Vessels exclusively solitary. Vessel-ray pits with distinct borders; similar to intervessel pits in size and shape throughout the ray cell and vessel ray pits with much reduced borders to apparently simple, often distinctly scalariform. Vascular/vasicentric tracheids present. Fibres with distinctly bordered pits, common on radial and tangential walls. Axial parenchyma diffuse, diffuse-in aggregates, and in bands up to three lines wide. Over eight cells per parenchyma strand. Rays exclusively uniseriate, all ray cells procumbent, rarely heterocellular mixed throughout the ray. Silica bodies in ray cells.

IAWA code: $2,5,9,13,22,25,30,32$, (45), (56), 60, 62, 63, 66, 69, (70), (76), 77, 86, 94, 96, 104, (109), 159, 160, 179.

Remark.

The Chrysobalanaceae present in the research area display a highly similar wood anatomy. Subtypes are therefore not made. A similar type was described and displayed as Parinari curatellifolia in Höhn (2005) and she provided references to earlier finds.

The charcoal type Monotes spp. (which was observed by the first author of this article in Bassar region sites which are not treated in the frame of this article), is highly similar and differs mainly in axial parenchyma distribution (not banded, in addition to the predominant apotracheal diffuse and diffuse-in-aggregates parenchyma, paratracheal sparse, vasicentric and aliform parenchyma is present in this type).

\section{Strychnos type spinosa}

Vessels in clusters. Intervessel pits minute to small, vesturing not discernible. Vessel-ray pits with distinct borders; similar to intervessel pits in size and shape throughout the ray cell. Paratracheal axial parenchyma aliform-confluent. Apotracheal parenchyma banded. 4-8 cells per parenchyma strand. Rays of two distinct sizes. Larger rays 4-10 seriate. Rays with procumbent, square and upright cells mixed throughout the ray. Mineral inclusions not observed.

IAWA code: $2,5,11,13,22,24,25,30,61,62,(63), 70,80,83,85$, 92, 93, 98, 102, 103, 108, 109, 179.

Remarks.

A similar charcoal type is described by Höhn (2005) as Strychnos spinosa. She did, however, not observe axial parenchyma and uniseriate rays. She provided references to earlier finds.

\section{Lannea spp.}

Vessels solitary, in small clusters and short rows. Vessel ray pits with much reduced borders to apparently simple, rounded or angular and vertical to horizontal. Axial parenchyma not observed. Fibres septate. Ray width 1-3 seriate, rays with canals wider. Body ray cells procumbent with 1-2 rows of upright and/or square marginal cells. Small radial canals present, but rare in the investigated material. Silica bodies present, in ray cells, in the investigated material abundant. Crystals not observed.

IAWA code: $2,5,13,22,26,27,31,32,56,61,65,69,75,97$, (98), $106,107,130,160,179$.

\section{Remark.}

A similar type was described and displayed in Höhn (2005) as Lannea sp., and she provided references to earlier finds. She 
considers the small diameter of the radial canals in combination with silica bodies in ray cells to be diagnostic when trying to separate Sahelo-Sudanian taxa in the Anacardiaceae and Burseraceae with otherwise similar wood anatomy.

\section{1. cf. Syzygium}

A single badly preserved fragment probably attributable to Syzygium spp. was found:

Vessels mainly in short rows. Intervessel pits virtually vestured. Axial parenchyma abundant, arrangement barely discernible (apotracheal diffuse-in-aggregates and aliform-confluent?). Vesselray pits with reduced borders to apparently simple. Rays 1 to 6 seriate. Body ray cells procumbent with mostly two to four cells rows of upright and/or square marginal cells; or procumbent, square and upright cells mixed throughout the ray.

IAWA code: 2, 5, 13, 22, 26, 29, 31?, 32, 61, 66, 77?, 80?, 83?, 107,

$109,179$.

Remark.

In transverse view, the fragment resembled Uapaca spp. in parenchyma distribution. The virtually vestured pits in combination with vessel-ray pits with reduced borders and relatively wide but not extremely high rays point to Syzygium. Modern charred material of Syzygium guineense was described and displayed in Eichhorn (2004).

\section{References}

African Plant Database, 2012. African Plant Database Version 3.4.0, Conservatoire et Jardin botaniques de la Ville de Genève and South African National Biodiversity Institute, Pretoria. Published on the internet [accessed May to August, 2017], from http://www.ville-ge.ch/musinfo/bd/cjb/africa/.

Alpern, S.B., 2005. Did they or didn't they invent it? Iron in sub-Saharan Africa. Hist. Afr. $32,41-94$

Arbonnier, M., 2002. Arbres, Arbustes et Lianes des Zones Sèches d'Afrique de I'Ouest. CIRAD-MNHN, Montpellier.

Ballouche, A., Dolidon, H., 2005. Forêts claires et savanes ouest-africaines: dynamiques et évolution de systèmes complexes à l'interface nature/société. In: Taabni, M. (Ed.), La forêt: Enjeux comparés des formes d'appropriation, de gestion et d'exploitation dans les politiques environnementales et le contexte d'urbanisation généralisée (Actes du colloque international à Poitiers), Mission de l'homme et de la Société (Université de Poitiers), Poitiers, pp. 56-70.

Baudena, M., Dekker, S.C., van Bodegom, P.M., Cuesta, B., Higgins, S.I., Lehsten, V. Reick, C.H., Rietkerk, M., Scheiter, S., Yin, Z., Zavala, M.A., Brovkin, V., 2015. Forests, savannas, and grasslands: bridging the knowledge gap between ecology and Dynamic Global Vegetation Models. Biogeosciences 12, 1833-1848.

Bayon, G., Dennielou, B., Etoubleau, J., Ponzevera, E., Toucanne, S., Bermell, S., 2012. Intensifying weathering and land use in Iron Age central Africa. Science 335 $1219-1222$.

Boffa, J.-M., 1999. Agroforestry Parklands in Sub-Saharan Africa. FAO, Rome.

Breman, H., Kessler, J.-J., 1995. Woody Plants in Agroecosystems of Semiarid Regions with an emphasis on the Sahelian Countries. Advanced Series in Agricultural Sciences 23. Springer, Berlin.

Brunel, J.F., 1981. Végétation. In: Gu-Konù, Y.E. (Ed.), (Dir.), Atlas du Togo. Les Éditions Jeune Afrique, Paris, pp. 16-17.

Brncic, T.M., Willis, K.J., Harris, D.J., Washington, R., 2007. Culture or climate? The relative influences of past processes on the composition of the lowland Congo rainforest. Philos. Trans. R. Soc. Lond. B Biol. Sci.. 362, 229-242.

Brunken, U., Schmidt, M., Dressler, S., Janssen, T., Thiombiano, A., Zizka, G., 2008 onwards. West African plants - A Photo Guide (www.westafricanplants. senckenberg.de). Forschungsinstitut Senckenberg, Frankfurt/Main, Germany.

Burkill, H.M., 1985-2000. The Useful Plants of West Africa. Royal Botanic Gardens, Kew, pp. $1-5$.

Carsan, S., Orwa, C., Harwood, C., Kindt, R., Stroebel, A., Neufeldt, H., Jamnadass, R. 2012. African Wood Density Database. World Agroforestry Centre, Nairobi.

Cartwright, C., Parkington, J., 1997. The wood charcoal assemblages from Eland's Bay Cave, southwestern Cape: principles, procedures and preliminary interpretation. South Afr. Archaeol. Bull. 52, 59-72.

Celis, G., 1991. Eisenhütten in Afrika/Les fonderies Africaines du fer. Museum für Völkerkunde, Frankfurt am Main.

Chirikure, S., 2015. Metals in Society: Indigenous African Metallurgy in a Global Perspective. Springer, New York.

Clément, J., 1982. Estimation des volumes et de la productivité des formations mixtes forestières et graminéennes tropicales. Données concernant les pays de l'Afrique francophone au nord de l'équateur et recommandations pour la conduite de nouvellesétudes. Bois Forêts des Tropiques 198, 35-58.

Corradi Pereira, B.L., Costa Oliveira, A., Carvalho, Macedo Ladeia Carvalho, A.M., de
Cassia Oliveira Carneiro, A., Carvalho Santos, L., Rocha Vital, B., 2012. Quality of wood and charcoal from Eucalyptus clones for ironmaster use. Int. J. For. Res. 2012, 523025 http://dx.doi.org/10.1155/2012/523025, 1-8.

De Barros, P., 1985. The Bassar: Large-scale Iron Producers of the West African Savanna. Ph.D. thesis. University of California at Los Angeles.

De Barros, P., 1986. Bassar: a quantified, chronologically controlled, regional approach to a traditional iron production center in West Africa. Africa, pp. $148-174$.

De Barros, P., 2012. The Bassar chiefdom in the context of theories of political economy. In: Robion-Brunner, C., Martinelli, B. (Eds.), Métallurgie du fer et sociétés africaines : bilans et nouveaux paradigmes dans la recherche anthropologique et archéologique. Bar International Series, vol. 2395, pp. 73-96.

De Barros, P., 2013. A comparison of early and later Iron Age societies in the Bassar region of Togo. In: Humphris, J., Rehren, T. (Eds.), The World of Iron. Archetype Publications, London, pp. 10-21.

Doat, J., 1975. La carbonisation des bois tropicaux. Bois Forêts des Tropiques 159, $55-71$.

Dugast, S., 1986. La pince et le soufflet: deux techniques de forge traditionnelles au Nord-Togo. J. des Afr. 56, 29-53.

Dugast, S., 2004. Une agglomération très rurale. Lien clanique et lien territorial dans la ville de Bassar (Nord-Togo). J. des Afr. 74, 203-248.

Dugast, S., 2012. Entre four et forge ou jusqu'à quel point efficacité magique et savoir technique sont-ils conciliables ? (Bassar du Togo). In: Robion-Brunner, C., Martinelli, B. (Eds.), Métallurgie du fer et sociétés africaines: bilans et nouveaux paradigmes dans la recherche anthropologique et archéologique. Bar International Series, vol. 2395, pp. 97-124.

Eichhorn, B., 2004. Anthrakologische Untersuchungen zur Vegetationsgeschichte des Kaokolandes, Nordwest-Namibia. Ph.D.Thesis. University of Cologne, Cologne. http://kups.ub.uni-koeln.de/volltexte/2004/1178/.

Eichhorn, B., 2012. Woody resource exploitation for iron metallurgy of the Fiko tradition: implications for the environmental history of the Dogon country, Mali. In: Robion-Brunner, C., Martinelli, B. (Eds.), Métallurgie du fer et sociétés africaines: bilans et nouveaux paradigmes dans la recherche anthropologique et archéologique. Archaeopress, Oxford, pp. 141-152.

Eichhorn, B., Neumann, K., 2013. Holocene vegetation change and land use at Ounjougou (Mali). In: Stevens, C., Nixon, S., Murray, M.A., Fuller, D.Q. (Eds.), Archaeology of African Plant Use. Leftcoast Press, Walnut Creek, pp. 83-96.

Eichhorn, B., Robion-Brunner, C., Perret, S., Serneels, V., 2013a. Fuel for iron - wood exploitation for metallurgy on the Dogon Plateau, Mali. In: Humphris, J., Rehren, T. (Eds.), The World of Iron. Archetype Publications, London, pp. $435-443$.

Eichhorn, B., Robion-Brunner, C., Perret, S., Serneels, V., 2013b. Iron metallurgy in the Dogon country (Mali): "deforestation" or sustainable use? In: Damblon, F. (Ed.), Proceedings of the 4th International Meeting of Anthracology, Brussels 813 September 2008, vol. 2486. Royal Belgian Institute of Natural Sciences, pp. 57-70. BAR International Series.

Ekblom, A., Eichhorn, B., Sinclair, P., Badenhorst, S., Berger, A., 2014. Land use history and resource utilisation, $400 \mathrm{AD}$ to the present, at Chibuene, southern Mozambique. Veg. Hist. Archaeobotany 23, 15-32.

El-Kamali, H.H., 2011. Detarium senegalense J.F.Gmel. In: Lemmens, R.H.M.J., Louppe, D., Oteng-Amoako, A.A. (Eds.), Prota 7(2): Timbers/Bois D'œuvre 2. PROTA, Wageningen, Netherlands. http://database.prota.org/PROTAhtml/ Detarium\%20senegalense_En.htm.

Fairhead, J., Leach, M., 1998. Reframing Deforestation. Global Analysis and Local Realities: Studies in West Africa. Routledge, New York.

Ferrero, G., 1894. L'inertie mentale et la loi du moindre effort. Revue Philosophique de la France de l'Étranger 37, 169-182.

Fuwape, J.A., 1993. Charcoal and fuel value of agroforestry tree crops. Agrofor. Syst. $22,175-179$

Fuwape, J.A., Akindele, S.O., 1997. Biomass yield and energy volume of some fastgrowing multipurpose trees in Nigeria. Biomass Bioenergy 12, 101-106.

Gallagher, D.E., 2010. Farming beyond the Escarpment: Society, Environment, and Mobility in Precolonial Southeastern Burkina Faso. Ph.D. thesis. University of Michigan.

Goucher, C.L., 1981. Iron is iron 'til it is rust: trade and ecology in the decline of West african iron-smelting. J. Afr. Hist. 22, 179-189.

Goucher, C.L., 1984. The iron industry of Bassar, Togo: an interdisciplinary investigation of African technological history. Ph.D. thesis. University of California. University Microfilms, Ann Arbor, Michigan.

Gu-Konù, Y.E., 1981a. Climat. In: Gu-Konù, Y.E. (Ed.), (Dir.), Atlas du Togo. Les Éditions Jeune Afrique, Paris, pp. 10-11.

Gu-Konù, Y.E., 1981b. Agriculture. In: Gu-Konù, Y.E. (Ed.), (Dir.), Atlas du Togo. Les Éditions Jeune Afrique, Paris, pp. 30-31.

Haaland, R., 1980. Man's role in the changing habitat of Mema during the old kingdom of Ghana. Nor. Archaeol. Rev. 13, 31-46.

Haaland, R., 1985. Iron production, its socio-cultural context and ecological implications. In: Haaland, R., Shinnie, P. (Eds.), African Iron Working - Ancient and Traditional. Norwegian University Press, Oslo, pp. 50-72.

Hahn, H.P., 1993. Eisentechniken in Nord-Togo. Kulturanthropologische Studien 21. LIT-Verlag, Münster, Hamburg.

Hahn, H.-P., 1997. Eisentechniken in Nord-Togo: kultur- und technikgeschichtliche Interpretationen. In: Klein-Arendt, R. (Ed.), Traditionelles Eisenhandwerk in Afrika, Colloquium Africanum 3. Heinrich-Barth-Institut, Köln, pp. 129-145.

Hepper, N., 1954-1972. Flora of West Tropical Africa. Crown Agents for Oversea Governments and Administrations, London. 
Herbert, E.W., Goucher, C., 1987. Resource Guide for the Blooms of Bandjeli: Technology and Gender in West African Ironmaking. Documentary Educational Resources, Waterton.

Höhn, A., 1999. Wood anatomy of selected West African species of Caesalpinioideae and Mimosoideae (Leguminosae): a comparative study. IAWA J. 20, 115-146.

Höhn, A., 2005. Zur eisenzeitlichen Entwicklung der Kulturlandschaft im Sahel von Burkina Faso. Untersuchungen von archäologischen Holzkohlen. Ph.D. Thesis. Goethe University, Frankfurt. http://publikationen.ub.uni-frankfurt.de/ volltexte/2005/2253/.

Höhn, A., Neumann, K., 2012. Shifting cultivation and the development of a cultural landscape during the Iron Age (0-1500 AD) in the northern Sahel of Burkina Faso, West Africa: insights from archaeological charcoal. Quat. Int. 249, 72-83.

Höhn, A., Neumann, K., 2016. The palaeovegetation of Janruwa (Nigeria) and its implications for the decline of the Nok Culture. J. Afr. Archaeol. http:// dx.doi.org/10.3213/2191-5784-10296.

Höhn, A., Neumann, K., accepted. Charcoal identification in a species-rich environment - the example of Dibamba, Cameroon. IAWA Journal.

Hubau, W., Van den Bulcke, J., Kitin, P., Mees, F., Van Acker, J., Beeckman, H., 2012. Charcoal identification in species-rich biomes: a protocol for Central Africa optimised for the Mayumbe forest. Rev. Palaeobot. Palynology 171, 164-178.

Hubau, W., Van den Bulcke, J., Kitin, P., Mees, F., Baert, G., Verschuren, D., Nsenga, L., Van Acker, J., Beeckman, H., 2013. Ancient charcoal as natural archive for paleofire regime and vegetation change in the Mayumbe, Democratic Republic of the Congo. Quat. Res. 80, 326-340.

Hubau, W., Van den Bulcke, J., Bostoen, K., Clist, B.O., Livingstone Smith, A., Defoirdt, N., Mees, F., Nsenga, L., Van Acker, J., Beeckman, H., 2014. Archaeological charcoals as archives for firewood preferences and vegetation composition during the late Holocene in the southern Mayumbe, Democratic Republic of the Congo (DRC). Veg. Hist. Archaeobotany 23, 591-606.

Huysecom, E., 2001. The beginning of iron metallurgy: from sporadic inventions to irreversible generalizations. In: Descoeudres, J.-P., Huysecom, E., Serneels, V., Zimmermann, J.-L. (Eds.), The Origins of Iron Metallurgy. Proceedings of the First International Colloquium on the Archaeology of Africa and the Mediterranean Basin. Mediterranean Archaeology, vol. 14, pp. 1-5.

IAWA Committee, 1989. IAWA list of microscopic features for hardwood identification. IAWA Bull. n.s 10, 219-332.

InsideWood, 2004 onwards. http://insidewood.lib.ncsu.edu/search.

Jansen, S., Robbrecht, E., Beeckman, H., Smets, E., 2002. A survey of the systematic wood anatomy of the Rubiaceae. IAWA J. 23, 1-67.

Kahlheber, K., 1999. Indications for agroforestry. Archaeobotanical remains of crops and woody plants from medieval Saouga, Burkina Faso. In: Van der Veen, M (Ed.), The Exploitation of Plant Resources in Ancient Africa. Kluwer Academic/ Plenum, New York, pp. 89-100.

Keita, M.N., 1982. Les disponibilités de bois de feu en région Sahélienne de l'Afrique Occidentale : situation et perspectives. FAO (Department of Forestry), Rome.

Kiethéga, J.-B., 2009. La métallurgie lourde du fer au Burkina Faso. Une technologie à l'époque précoloniale. Éditions Karthala, Paris.

Killick, D., 2004. Review Essay. What do we know about African iron working? J. Afr Archaeol. 2, 97-112.

Klašnja, B., Orlović, S., Galić, Z., 2013. Comparison of different wood species as raw materials for bioenergy. South-East Eur. For. 4, 81-88.

Kouami, K., Yaovi, N., Honan, A., 2009. Impact of charcoal production on woody plant species in West Africa: a case study in Togo. Sci. Res. Essay 4, 881-893.

Lespez, L., Le Drezen, Y., Garnier, A., Rasse, M., Eichhorn, B., Ozainne, S., Ballouche, A., Neumann, K., Huysecom, E., 2011. High-resolution fluvial records of Holocene environmental changes in the Sahel: the Yamé River at ounjougou (Mali, West Africa). Quat. Sci. Rev. 30, 737-756.

Lézine, A.M., Holl, A.F.C., Lebamba, J., Vincens, A., Assi-Khaudjis, C., Février, L. Sultan, E., 2013. Temporal relationship between Holocene human occupation and vegetation change along the northwestern margin of the Central African rainforest. Comptes Rendus Geosci. 345, 327-335.

Luoga, E.J., Witkowski, E.T.F., Balkwill, K., 2002. Harvested and standing wood stocks in protected and communal miombo woodlands of eastern Tanzania. For. Ecol. Manag. 164, 15-30.

Maley, J., 2004. Les variations de la végétation et des paléoenvironnements du domaine forestier africain au cours du Quaternaire récent. In: RenaultMiskovsky, J., Semah, A.M. (Eds.), Guide de la préhistoire mondiale. Artcom'/ Errance, Paris, pp. 143-178.

Maley, J., Giresse, P., Doumenge, C., Favier, C., 2012. Comment on "Intensifying weathering and land use in Iron Age Central Africa". Science 337, 1040-d.

Marston, J.M., 2009. Modeling wood acquisition strategies from archaeological charcoal remains. J. Archaeol. Sci. 36, 2129-2200.

Maydell, H.-J., 1990. Trees and Shrubs of the Sahel: Their Characteristics and Uses, Margraf, Weikersheim.

Martinelli, B., 1982. Métallurgistes Bassar. Etudes/Documents de Sciences Humaines 5, Lomé.

Martinelli, B., 1984. La production des outils agricoles en pays Basar (Nord-Togo). Cah. ORSTOM Série Sci. Hum. 20, 485-504.

Martinelli, B., 1992. Les métallurgistes du fer en Afrique de l'Ouest. In: Blandin, A. (Ed.), Fer noir d'Afrique de l'Ouest. A. Blandin, Marseille, pp. 14-20.

Munalula, F., Meincken, M., 2009. An evaluation of South African fuelwood with regards to calorific value and environmental impact. Biomass Bioenergy 33, 415-420.

National Academy of Sciences, 1980 (Washington DC: US National Research Council). Firewood Crops. Shrub and Tree Species for Energy Production, vol. 1.
Neumann, K., Kahlheber, S., Übel, D., 1998. Remains of woody plants from Saouga, a medieval West African village. Veg. Hist. Archaeobotany 7, 57-77.

Neumann, K., Schoch, W., Détienne, P., Schweingruber, F.H., 2001. Hölzer der Sahara und des Sahel. Woods of the Sahara and the Sahel. Bois du Sahara et du Sahel. Paul Haupt, Bern.

Neumann, K., Hahn-Hadjali, K., Salzmann, U., 2004. Die Savannen der Sudanzone in Westafrika: natürlich oder menschengemacht? In: Albert, K.D., Löhr, D. Neumann, K. (Eds.), Mensch und Natur in West-Afrika. Wiley-VCH, Weinheim, pp. 39-68.

Neumann, K., Eggert, M.K.H., Oslisly, R., Clist, B., Denham, T., de Maret, P., Ozainne, S., Hildebrand, E., Bostoen, K., Salzmann, U., Schwartz, D., Eichhorn, B., Tchiengué, B., Höhn, A., 2012. Comment on "Intensifying weathering and land use in Iron Age central Africa". Science 337, 1040-c.

Nygard, R., Elfving, B., 2000. Stem basic density and bark proportion of 45 woody species in young savanna coppice forests in Burkina Faso. Ann. For. Sci. 57, $143-153$.

Pelzer, C., Müller, J., Albert, K.-D., 2004. Die Nomadisierung des Sahel - Siedlungsgeschichte, Klima und Vegetation in der Sahelzone von Burkina Faso in historischer Zeit. In: Albert, K.-D., Löhr, D., Neumann, K. (Eds.), Mensch und Natur in West-Afrika. Wiley VCH, Weinheim, pp. 256-288.

Petit, M., 1981. Géomorphologie. In: Gu-Konù, Y.E. (Ed.), (Dirr.), Atlas du Togo. Les Éditions Jeune Afrique, Paris, pp. 8-9.

Picard, N., Ouattara, S., Diarisso, D., Ballo, M., Gautier, D., 2006. Defining units for savanna management in Sudano-Sahelian areas. For. Ecol. Manag. 236, 403-411.

Prior, J.A.B., Price-Williams, D., 1985. An investigation of climatic change in the Holocene epoch using archaeological charcoal from Swaziland, southern Africa. J. Archaeol. Sci. 12, 457-475.

Punt, W., Blackmore, S., Hoen, P.P., Stafford, P.J., 2003. The Northwest European Pollen Flora. Elsevier Science, Amsterdam.

Reimer, P.J., Bard, E., Bayliss, A., Beck, J.W., Blackwe ll, P.G., Bronk Ramsey, C. Grootes, P.M., Guilderson, T.P., Haflidason, H., Hajdas, I., Hatté, C., Heaton, T.J. Hoffmann, D.L., Hogg, A.G., Hughen, K.A., Kaiser, K.F., Kromer, B., Manning, S.W. Niu, M., Reimer, R.W., Richards, D.A., Scott, E.M., Southon, J.R., Staff, R.A., Turney, C.S.M., van der Plicht, J., 2013. IntCal13 and Marine13 radiocarbon age calibration curves 0-50,000 Years cal BP. Radiocarbon 55, 1869-1887.

Reyes, G., Brown, S., Chapman, J., Lugo, A.E., 1992. Wood densities of Tropical Tree Species. General Technical Report SO-88. USDA Forest Service, Southern Forest Experiment Station, New Orleans, Louisiana, USA.

Robion-Brunner, C., 2010. Peuplements des forgerons et traditions sidérurgiques : vers une histoire de la production du fer sur le plateau de Bandiagara (pays dogon, Mali) durant les empires précoloniaux. Monographie du programme Paléoenvironnement et peuplement humain en Afrique de l'Ouest. J. Afr Archaeol. Frankfurt.

Robion-Brunner, C., Serneels, V., 2017. Protéger et fouiller un site archéologique. Sites Métallurgiques. In: Livingstone Smith, A., Cornelissen, E., Gosseleain, O. MacEachern, S. (Eds.), Field Manual for African Archaeology, chapter 3. Online Series " Collection digitale Documents de Sciences humaines et sociales, pp. 129-133. FMAA (Musée Royale de l'Afrique Centrale, Tervuren). http:// www.africamuseum.be/docs/publications/FMAA/fr/LR/chapters/FRA_FMA_ Chap3 LR.pdf.

Robion-Brunner, C., Serneels, V., Perret, S., 2013. Variability in iron smelting practices: assessment of technical, cultural and economic criteria to explain the metallurgical diversity in the Dogon area (Mali). In: Humphris, J., Rehren, T. (Eds.), The World of Iron. Archetype Publications, London, pp. 257-265.

Salzmann, U., Hoelzmann, P., 2005. The Dahomey Gap: an abrupt climatically induced rain forest fragmentation in West Africa during the late Holocene. Holocene 15, 190-199.

Salzmann, U., Waller, M., 1998. The Holocene vegetational history of the Nigerian Sahel based on multiple pollen profiles. Rev. Palaeobot. Palynology 100, 39-72.

Salzmann, U., 2000. Are savannas degraded forests? - A Holocene pollen record from the Sudanian zone of NE-Nigeria. Veg. Hist. Archaeobotany 9, 1-15.

Salzmann, U., Hoelzmann, P., Morczinek, I., 2002. Later Quaternary climate and vegetation of the Sudanian zone of NE-Nigeria deduced from pollen, diatoms and sedimentary geochemistry. Ouat. Res. 58, 73-83.

Seddoh, K.F., 1981. Géologie. In: Gu-Konù, Y.E. (Ed.), (Dir.), Atlas du Togo. Les Éditions Jeune Afrique, Paris, pp. 6-7.

Serneels, V., Eichhorn, B., Kiénon-Kaboré, H.T., N'Zebo, L., Ramseyer, D., ThiombianoIlboudo, E. Yéo, A., 2016. Origine et développement de la métallurgie du fer au Burkina Faso et en Côte d'Ivoire (5). Prospections et sondages dans la région de Yamane (Burkina Faso) et en recherches à Siola 4000 (Côte d'Ivoire). SLSA Rapport Annuel 2015.

Shackleton, C.M., Prins, F., 1992. Charcoal analysis and the principle of least effort - a conceptual model. J. Archaeol. Sci. 19, 631-637.

Shanahan, T.M., Overpeck, J.T., Scholz, C.A., Beck, J.W., Peck, J., King, J.W., 2008 Abrupt changes in the water balance of tropical West Africa during the late Quaternary. J. Geophys. Res. 113 http://dx.doi.org/10.1029/2007JD009320.

Shelton, J., Shapiro, A.B., 1976. Wood as Energy: the Wood Burner's Encyclopedia Vermont Crossroads Press, Waitsfield.

Sotelo Montes, C., Agostinho da Silva, D., Garcia, R.A., Bolzón de Muňiz, G.I., Weber, J.C., 2011. Calorific value of Prosopis africana and Balanites aegyptiaca wood: relationships with tree growth, wood density and rainfall gradients in the West African Sahel. Biomass Bioenergy 35, 346-353.

Teklehaimanot, Z., 2004. Exploiting the potential of indigenous agroforestry trees: Parkia biglobosa and Vitellaria paradoxa in sub-Saharan Africa. Agrofor. Sytems 
61, 207-220

Théry-Parisot, I., Chabal, L., Chrzavzez, J., 2010. Anthracology and taphonomy, from wood gathering to charcoal analysis. A review of the taphonomic processes modifying charcoal assemblages, in archaeological contexts. Palaeogeogr. Palaeoclimatol. Palaeoecol. 291, 142-153.

Thompson, G., Young, R., 1999. Fuels for the furnace. Recent and prehistoric ironworking in Uganda and beyond. In: Van der Veen, M. (Ed.), The Exploitation of Plant Resources in Ancient Africa. Kluwer Academic/Plenum, New York, pp. 221-239.

Tietema, T., Dithogo, M., Tibone, C., Mathalaza, N., 1991. Characteristics of eight firewood species in Botswana. Biomass Bioenergy vol. 1, 41-46.

Von Maltitz, G.P., Scholes, R.J., 1995. Burning of fuelwood in South Africa: when is it sustainable? Environ. Monit. Assess. 38, 243-251.

Wala, K., Sinsin, B., Guelly, K.A., Kokou, K., Koffi, A., 2005. Typologie et structure des parcs agroforestiers dans la préfecture de Doufelgou (Togo). Sécheresse 16, 209-216.

Warnier, J.P., Fowler, I., 1979. A nineteenth century Ruhr in central Africa. Africa 49, 329-351.

Weber, J.C., Sotelo Montes, C., Abasse, T., Sanquetta, C.R., Silva, D.A., Mayer, S. Muňiz, G.I., Garcia, R.A., 2017. Variation in growth, wood density and carbon concentration in five tree and shrub species in Niger. New For. http://dx.doi.org/ 10.1007/s11056-017-9603-7.

Zakrzewski, S., Shortland, A., Rowland, J., 2016. Science in the Study of Ancient Egypt. Routledge/Taylor and Francis, New York and London (Routledge Studies in Egyptology 3).

Zipf, G.K., 1949. Human Behavior and the Principle of Least Effort, Oxford. AddisonWesley Press. 